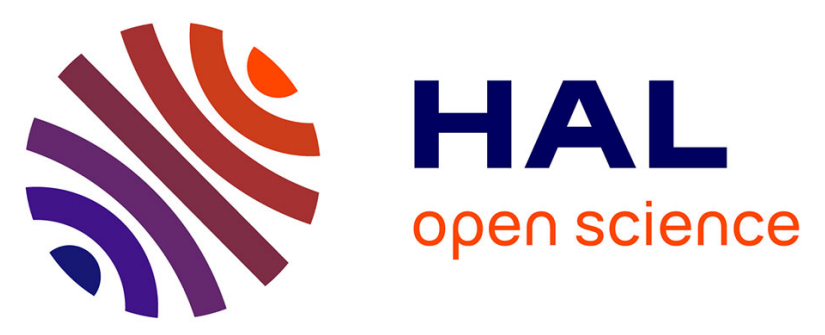

\title{
In Situ Analysis of Weakly Bound Proteins Reveals Molecular Basis of Soft Corona Formation
}

Daniel Sanchez-Guzman, Gaël Giraudon-Colas, Laurent Marichal, Yves Boulard, Frank Wien, Jéril Degrouard, Armelle Baeza-Squiban, Serge Pin, Jean Philippe Renault, Stephanie Devineau

\section{To cite this version:}

Daniel Sanchez-Guzman, Gaël Giraudon-Colas, Laurent Marichal, Yves Boulard, Frank Wien, et al.. In Situ Analysis of Weakly Bound Proteins Reveals Molecular Basis of Soft Corona Formation. ACS Nano, 2020, 17, pp.9073-9088. 10.1021/acsnano.0c04165 . cea-02894519

\section{HAL Id: cea-02894519 https://hal-cea.archives-ouvertes.fr/cea-02894519}

Submitted on 9 Jul 2020

HAL is a multi-disciplinary open access archive for the deposit and dissemination of scientific research documents, whether they are published or not. The documents may come from teaching and research institutions in France or abroad, or from public or private research centers.
L'archive ouverte pluridisciplinaire HAL, est destinée au dépôt et à la diffusion de documents scientifiques de niveau recherche, publiés ou non, émanant des établissements d'enseignement et de recherche français ou étrangers, des laboratoires publics ou privés. 


\title{
In situ analysis of weakly bound proteins reveals molecular basis of soft corona formation
}

\author{
Daniel Sanchez-Guzman, ${ }^{\mathrm{a}}$ Gaël Giraudon--Colas, ${ }^{\mathrm{b}}$ Laurent Marichal, ${ }^{\mathrm{c}}$ Yves Boulard, ${ }^{\mathrm{d}}$ Frank \\ Wien, ${ }^{\mathrm{e}}$ Jéril Degrouard, ${ }^{\mathrm{c}}$ Armelle Baeza-Squiban, ${ }^{\mathrm{a}}$ Serge Pin, ${ }^{\mathrm{b}}$ Jean Philippe Renault, ${ }^{\mathrm{b}}$ and \\ Stéphanie Devineau*a \\ a Université de Paris, BFA, UMR 8251, CNRS, F-75013 Paris, France \\ b Université Paris-Saclay, CEA, CNRS, NIMBE, Gif-sur-Yvette 9119o, France \\ c Université Paris-Saclay, CNRS, Laboratoire de Physique des Solides, 91405 Orsay Cedex, France \\ d Université Paris-Saclay, CEA, CNRS, I2BC, B3S, Gif-sur-Yvette 9119o, France \\ e Synchrotron SOLEIL, 91192 Gif-sur-Yvette, France
}

\begin{abstract}
Few experimental techniques allow the analysis of the protein corona in situ. As a result, little is known on the effects of nanoparticles on weakly bound proteins that form the soft corona. Despite its biological importance, our understanding of the molecular bases driving its formation is limited. Here we show that hemoglobin can form either a hard or a soft corona on silica nanoparticles depending on the $\mathrm{pH}$ conditions. Using cryoTEM and synchrotron-radiation circular dichroism, we show that nanoparticles alter the structure and the stability of weakly bound proteins in situ. Molecular dynamics simulation identified the structural elements driving protein-nanoparticle interaction. Based on thermodynamic analysis, we show that nanoparticles stabilize partially unfolded protein conformations by enthalpy-driven molecular interactions. We suggest that nanoparticles alter weakly bound proteins by shifting the equilibrium towards the unfolded states at physiological temperature. We show that the classical approach based on nanoparticle separation from the biological medium fails to detect destabilization of weakly bound proteins, and therefore cannot be used to fully predict the biological effects of nanomaterials in situ.
\end{abstract}

KEYWORDS. Protein corona, silica nanoparticles, cryoTEM, synchrotron-radiation circular dichroism, molecular dynamics, protein unfolding.

In a biological environment, the adsorption of proteins on nanoparticles (NPs) is an early process that leads to major changes of the physicochemical properties and the biological effects of NPs. ${ }^{1-3}$ The formation of the so-called protein corona drives NP-cell interaction, NP biodistribution, and NP toxicity in vivo..$^{-7}$ Numerous studies have investigated the composition and dynamics of the protein corona in various biological systems on one hand, and the changes of the structure and activity of adsorbed proteins on the other. $^{8-12}$ The current paradigm is that one protein may or may not have affinity for one NP, depending on (i) the protein structural and biochemical properties, (ii) the NP size, shape, and surface chemistry, (iii) the $\mathrm{pH}$, ionic strength and composition of the medium..$^{13-16}$ In a model system where one protein encounters one NP, this would result in either the adsorption or the non-adsorption of the protein on the surface. In a more complex biological environment where competitive adsorption occurs, protein adsorption will also depend on the affinity scale of the different proteins and on their concentration in the medium. Proteins with high abundance and lower affinity may be gradually replaced by proteins with higher affinity. ${ }^{17}$ The formation of the protein corona is a dynamic process that evolves with time, ${ }^{8,18}$ changes of the biological medium, ${ }^{19}$ and through cell processing. ${ }^{20}$ In vitro and in vivo studies have recently shown that flow plays a significant role in shaping the protein corona on NPs in a biological environment. ${ }^{21-23}$ Methodologies have been developed to identify and quantify proteins adsorbed on NPs. ${ }^{24}$ In most cases, the adsorbed proteins are separated from the free proteins in solution by centrifugation. The pellet (which contains NPs coated with proteins) and the supernatant (which contains free proteins) are then analyzed by proteomics to determine the composition of the corona. These information are used to determine the structural and physicochemical parameters driving protein adsorption. ${ }^{13,14}$

Proteins that are weakly bound to the surface may be lost during the separation steps. They are referred to as the soft corona as opposed to the hard corona composed of tightly bound proteins that remain adsorbed after NP separation. ${ }^{25}$ The reshuffling of the corona was described by Pisani et al. who compared its composition following the separation of magnetic silica NPs by centrifugation or magnetization. ${ }^{26}$ While the separation steps are known to alter the 
composition of the protein corona (see the review by Weber et al. on the different separation techniques ${ }^{27}$ ), most studies of protein adsorption are still performed following the classical approach of incubation and separation of NPs from the biological medium before protein analysis. One reason is that there are few techniques to analyse the protein corona in situ. A methodology based on flow cytometry and immunolabelling was developed to quantify the adsorption of a few specific proteins on NPs in human serum. ${ }^{28}$ The analysis of the hydrodynamic radius (or gyration radius) of NPs coated by proteins using fluorescence correlation spectroscopy, ${ }^{29}$ small-angle neutron scattering, $3^{30} \mathrm{NMR}^{31,3^{2}}$ or confocal laser scanning microscopy 33 can also provide information on the formation of the protein corona in solution. Here we introduce another approach based on cryoTEM and synchrotron-radiation circular dichroism (SRCD) to detect changes in protein structure and stability mediated by nanoparticles in situ (Figure 1).

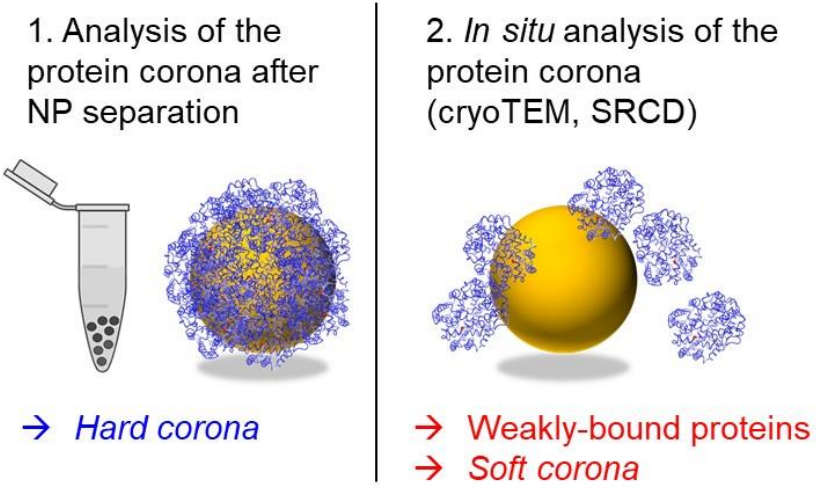

Figure 1. Schematic representation of the analysis of the hard corona following NP separation (1), and the in situ analysis of weakly-bound proteins and the soft corona by cryoTEM and $\operatorname{SRCD}(2)$.

Changes in protein structure and activity following adsorption on NPs (and more generally on inorganic surfaces) have been well documented in the literature.9,12,34,35 Based on these observations, it was hypothesized that NPs may also have a biological impact by affecting protein structure and activity, for example by triggering an immune response following modifications of protein conformation or by altering the activity of an enzyme. ${ }^{10}$ It implicitly assumes that biological effects of NPs on proteins would result from protein adsorption on NPs, as evidenced by the formation of a hard corona.

In this study, we show that the classical approach based on NP separation from the biological medium fails to detect protein destabilization mediated by weak protein-NP interactions, and therefore cannot be used to fully predict biological effects of nanomaterials in situ.

We investigated the effect of silica nanoparticles (SNPs) on the structure and stability of a model protein, oxyhemoglobin (oxyHb), by SRCD. OxyHb is the functional oxygenated form of hemoglobin. Monodisperse Ludox TM50 silica nanoparticles with a mean diameter of $26.0 \mathrm{~nm}^{30,36}$ were used to investigate their effect on the structure of oxyHb. Previously, we reported that oxyHb strongly adsorbs on SNPs at $\mathrm{pH}$, but does not form a hard corona on SNPs at $\mathrm{pH} 9 .{ }^{35,37}$
We used these two $\mathrm{pH}$ conditions to investigate the molecular mechanisms and the structural effects of strong versus weak protein-NP interactions respectively during oxyHb thermal unfolding.

\section{RESULTS AND DISCUSSION}

First, we checked for the stability of SNPs in the 3 buffers chosen for the SRCD experiments: $100 \mathrm{mM}$ phosphate buffer $\mathrm{pH} 7,5 \mathrm{mM}$ ammonium acetate $\left(\mathrm{NH}_{4} \mathrm{Ac}\right)$ buffer $\mathrm{pH}$ 9, and $3 \mathrm{mM} \mathrm{N}$-Cyclohexyl-2-aminoethanesulfonic acid (CHES) buffer $\mathrm{pH}$ 9. Two buffer conditions were chosen at $\mathrm{pH} 9$ to take into account potential ionic effects on protein-NP interactions. Experiments were conducted in phosphate buffer only at $\mathrm{pH} 7$ because we did not observe any major buffer effect on the adsorption of oxyHb on SNPs at this $\mathrm{pH} .{ }^{35}$ There is no difference in size or aggregation state of SNPs at $\mathrm{pH} 7$ nor at $\mathrm{pH} 9$ in the different buffer conditions (Figure $\mathrm{S}_{1}$ ). The surface charge of SNPs is very similar at $\mathrm{pH} 7$ and at $\mathrm{pH}$, as indicated by the $\zeta$-potential values: $\zeta=-42.1 \pm 2.2 \mathrm{mV}, \zeta=-45.1 \pm 0.5 \mathrm{mV}$ and $\zeta=-47.3 \pm 1.3 \mathrm{mV}$ in phosphate buffer $\mathrm{pH}$, in $\mathrm{NH}_{4} \mathrm{Ac}$ buffer $\mathrm{pH}$ 9, and in CHES buffer $\mathrm{pH} 9$ respectively. We did not observe any dissolution of SNPs at $\mathrm{pH} 9$ over time (Figure $\mathrm{S}_{1}$ ).

\section{OxyHb forms a hard corona on SNPs at $\mathrm{pH}_{7}$}

The adsorption isotherm of oxyHb on SNPs at $\mathrm{pH} 7$ is shown in Figure 2a. The adsorption constant $K_{a d s}$ was calculated using the Langmuir model assuming reversible adsorption. ${ }^{88}$ The Langmuir model relates the amount of adsorbed protein to the free protein concentration in solution for a fixed amount of binding sites that is for a fixed NP concentration (eq 1$)$ :

$$
m_{a d s}=\frac{m_{\infty} * K_{a d s} * C_{p}}{1+K_{a d s} * C_{p}}
$$

where $C_{p}$ is the free protein concentration at equilibrium, $m_{a d s}$ the amount of adsorbed protein, $m_{\infty}$ the maximum amount of adsorbed protein. Here we measured the amount of adsorbed protein as a function of NP concentration, for a fixed protein concentration.

We adapted the Langmuir model to fit the adsorption isotherms (eq 2):

$$
\%_{a d s}=\frac{\left(n \times C_{N P}+C_{\text {protein }}+\frac{1}{K_{\text {ads }}}\right)-\sqrt{\left(n \times C_{N P}+C_{\text {protein }}+\frac{1}{K_{\text {ads }}}\right)^{2}-4 \times n \times C_{N P} \times C_{\text {protein }}}}{2 C_{\text {protein }}} \text { (eq 2) }
$$

where $\%$ ads is the percentage of adsorbed protein, $\mathrm{C}_{\mathrm{NP}}$ the NP concentration $(\mathrm{mol} / \mathrm{L})$, and $\mathrm{C}_{\text {protein }}$ the initial protein concentration. The quantity n. $C_{N P}$ represents the concentration of binding sites, with $n$ the number of binding sites per NP. The adsorption isotherms measured at $\mathrm{pH} 7$ with two protein concentrations (0.5 $\mathrm{mM}$ and $1 \mathrm{mM}$ oxyHb) are accomodated by the model (Figure 2a).

The adsorption constant $K_{a d s}=2.110^{5} \mathrm{M}^{-1}$ and the amount of adsorbed protein $m_{\infty}=\mathbf{2 . 2} \mathrm{mg} / \mathrm{m}^{2}$ reflect the high affinity of oxyHb for SNPs at $\mathrm{pH}$ 7. In the conditions used for the SRCD measurements $\left(C_{\text {oxyHb }}=1 \mathrm{mM}, C_{\mathrm{SNP}}=100 \mathrm{mg} / \mathrm{mL}\right), 97 \%$ of oxyHb molecules are adsorbed on the SNPs at $\mathrm{pH} 7$ at $22^{\circ} \mathrm{C}$ after NP centrifugation. These conditions were chosen so that the SRCD spectra of adsorbed oxyHb could be recorded in situ without any contribution from the free 
a

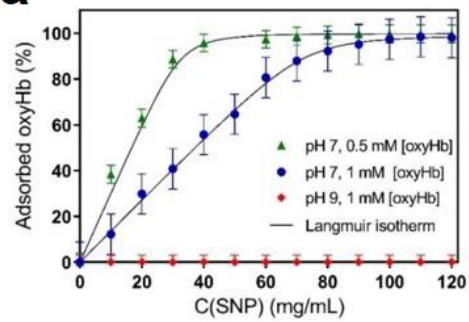

C

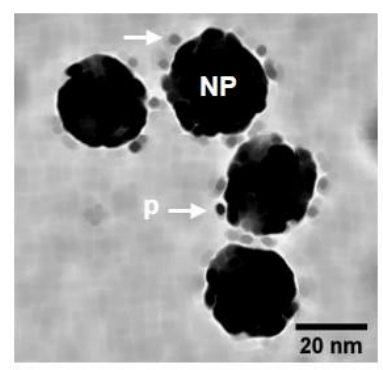

d

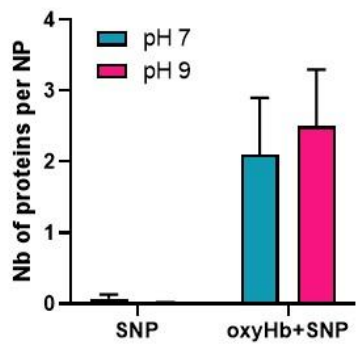

b

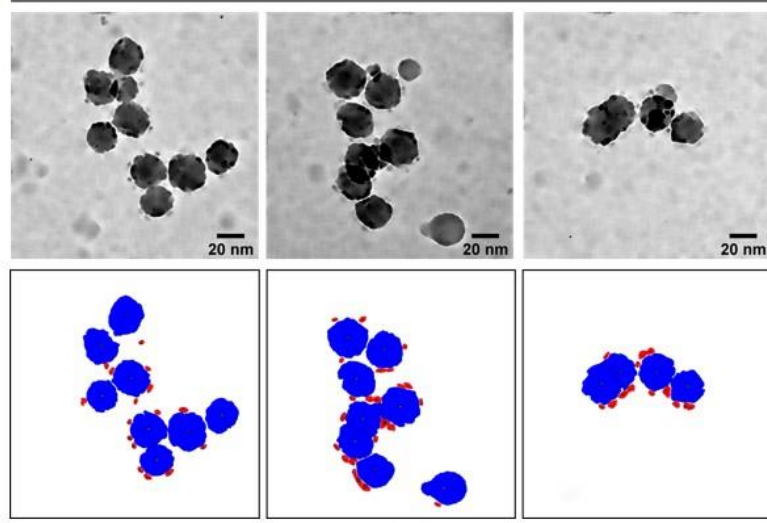

$\mathrm{oxyHb}+\mathrm{SNP} \mathrm{pH} 9$
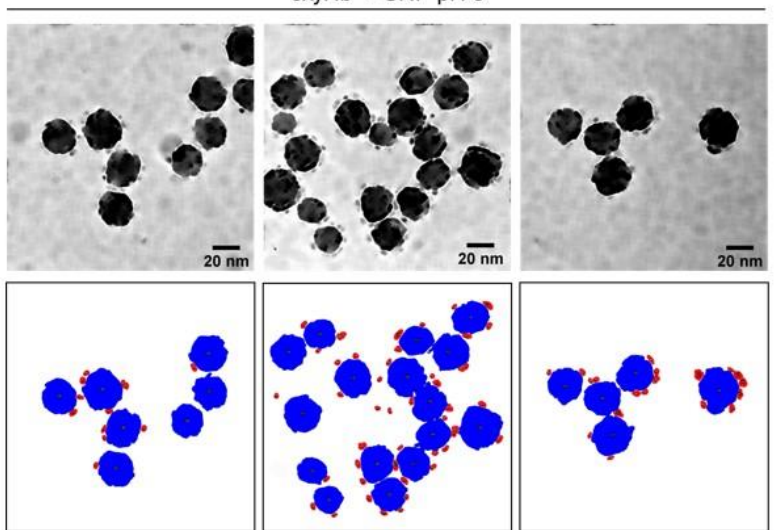

SNP pH 7

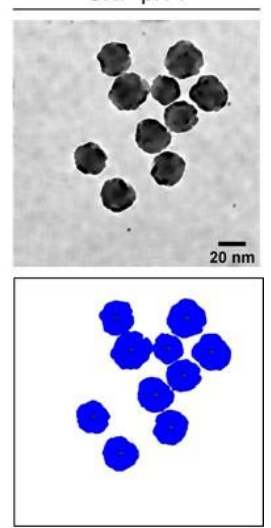

SNP $\mathrm{pH} 9$

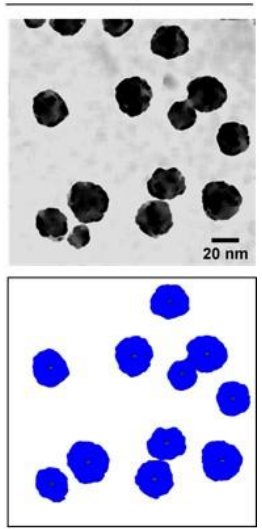

Figure 2. Identification of the hard corona and soft corona formed by oxyHb on SNPs. (a) Adsorption isotherms of oxyHb on SNPs in phosphate buffer at $\mathrm{pH} 7$ and in $\mathrm{NH}_{4} \mathrm{Ac}$ buffer at $\mathrm{pH} 9$ at $22^{\circ} \mathrm{C}$. $\mathrm{C}($ oxyHb $)=0.5 \mathrm{mM}$ and $1 \mathrm{mM}$. At $\mathrm{pH} 9,<3 \%$ oxyHb is adsorbed on SNPs after NP centrifugation. Fit by the Langmuir model is shown at pH 7 only. (b) CryoTEM images of SNPs with and without oxyHb at $\mathrm{pH} 7$ and at $\mathrm{pH}$ 9. The results of automated particle analysis of SNPs (in blue) and adsorbed oxyHb (in red) are shown below. (c) Zoom on the cryoTEM image of SNPs (NP) with adsorbed oxyHb (p) at pH 9. Some adsorbed proteins are indicated by a white arrow. (d) Number of proteins adsorbed per SNP at $\mathrm{pH} 7$ and at $\mathrm{pH} 9$ identified by automated analysis of the cryoTEM images in 2D projection. A minimum of 100 SNPs were analyzed in each condition.

proteins in solution at $\mathrm{pH}$ 7. A hard corona of oxyHb forms on SNPs at $\mathrm{pH} 7$.

\section{OxyHb forms a soft corona on SNPs at pH 9}

In contrast, no oxyHb (within the experimental error of $3 \%$ ) was adsorbed on SNPs at $\mathrm{pH} 9$ in $\mathrm{NH}_{4}$ Ac buffer or in CHES buffer following NP separation. To check whether this observation resulted from a lack of protein-NP interaction at $\mathrm{pH} 9$ or from a loss of weakly-bound proteins during the separation step, we analysed the SNPs in situ by cryoTEM (Figure 2b, 2c). CryoTEM imaging was performed with an excess of proteins in solution to maximize corona formation. The presence of proteins at the surface of SNPs is clearly visible both in phosphate buffer at $\mathrm{pH} 7$ and in $\mathrm{NH}_{4} \mathrm{Ac}$ buffer at $\mathrm{pH}$ 9. The high resolution of the cryoTEM images makes it possible to identify individual nanoparticles and adsorbed proteins based on their size differences (Figure 2b). Automated image analysis was developed with ImageJ software for this purpose (see Methods, Table $\mathrm{S}_{1}$ ). Untreated images are shown in Figure $\mathrm{S}_{2}$. The same parameters were applied to all the images. Free proteins were excluded from the analysis. A minimum number of 100 nanoparticles was automatically analyzed in each condition.
The average diameter of SNPs was $25.6 \pm 0.6 \mathrm{~nm}$, in agreement with published data. ${ }^{30,36}$ The average diameter of adsorbed proteins was calculated assuming a spherical shape. A diameter of $4.7 \pm 0.2 \mathrm{~nm}$ was measured at $\mathrm{pH} 7$ and at $\mathrm{pH}$ 9, close to the value reported for native porcine hemoglobin $(\mathrm{d}=4.6 \mathrm{~nm})$. Interestingly, a SANS study showed that little modification of oxyHb shape occurs following adsorption onto SNPs. ${ }^{30}$ The cryoTEM images show that oxyHb adsorbs on SNPs both at $\mathrm{pH} 7$ and at $\mathrm{pH} 9$ (Figure $2 \mathrm{~b}, 2 \mathrm{c}, 2 \mathrm{~d})$. This observation is confirmed by the automated image analysis, which detected a minimum of 2 adsorbed proteins on SNPs both at $\mathrm{pH} 7$ and at $\mathrm{pH} 9$ for more than 100 nanoparticles analyzed (Figure $\mathrm{S}_{2}$ ). The number of proteins per NP (Figure 2d) reflects the number of adsorbed proteins detected automatically in a $2 \mathrm{D}$ projection. This indicator does not quantify the number of proteins in the corona, but provides a numerical value to evaluate the presence or absence of adsorbed proteins from the observation of a larger number of objects by cryoTEM. It confirms that oxyHb adsorbs onto SNPs both at $\mathrm{pH}_{7}$ and at $\mathrm{pH} 9$ in situ. The adsorption of oxyHb on SNPs at $\mathrm{pH} 9$ was not seen in the adsorption isotherm (Figure 2a) suggesting that adsorbed oxyHb is lost following SNP centrifugation. These results show that oxyHb forms a soft corona of weakly 
bound proteins on SNPs at $\mathrm{pH}$ 9, whereas it can form a hard corona that is retained after SNP centrifugation at $\mathrm{pH}$ 7. Therefore oxyHb can form either a hard or a soft corona on SNPs depending on $\mathrm{pH}$ conditions. Here, the formation of the soft corona was observed in situ by cryoTEM analysis.

In situ structural analysis of adsorbed proteins by SRCD

Following this observation, we investigated the effect of SNPs on oxyHb secondary structure in the hard corona or in the soft corona in situ at $\mathrm{pH} 7$ and at $\mathrm{pH} 9$ respectively by SRCD (Figure 3). The high photon fluxes provided by SRCD in the UV region can be used to access additional electronic transitions of the polypeptide backbone from $170 \mathrm{~nm}$ to $260 \mathrm{~nm}$ and to accurately detect changes in protein secondary structures in colloidal suspensions.39,40 The SRCD spectra of free oxyHb are identical at $\mathrm{pH} 7$ and at $\mathrm{pH}$ 9 in the 3 buffers (Figure $\mathrm{S}_{3}$ ) showing that the average secondary structure of oxyHb does not vary between $\mathrm{pH} 7$ and $\mathrm{pH}$ 9. The SRCD spectrum of oxyHb is characterized by two minima at $222 \mathrm{~nm}$ and $209 \mathrm{~nm}$, and a maximum at 194 $\mathrm{nm}$ with a shoulder around $175 \mathrm{~nm}$. These features are typical of proteins with a predominant $\alpha$-helical secondary structure. The peaks originate from the $n \rightarrow \pi^{*}$ electronic backbone transition (222 $\mathrm{nm}$ ) and the exciton splitting of the $\pi \rightarrow \pi^{*}$ transition (194 $\mathrm{nm}$ and $209 \mathrm{~nm}$ ) which is specific to helical structures. ${ }^{41}$
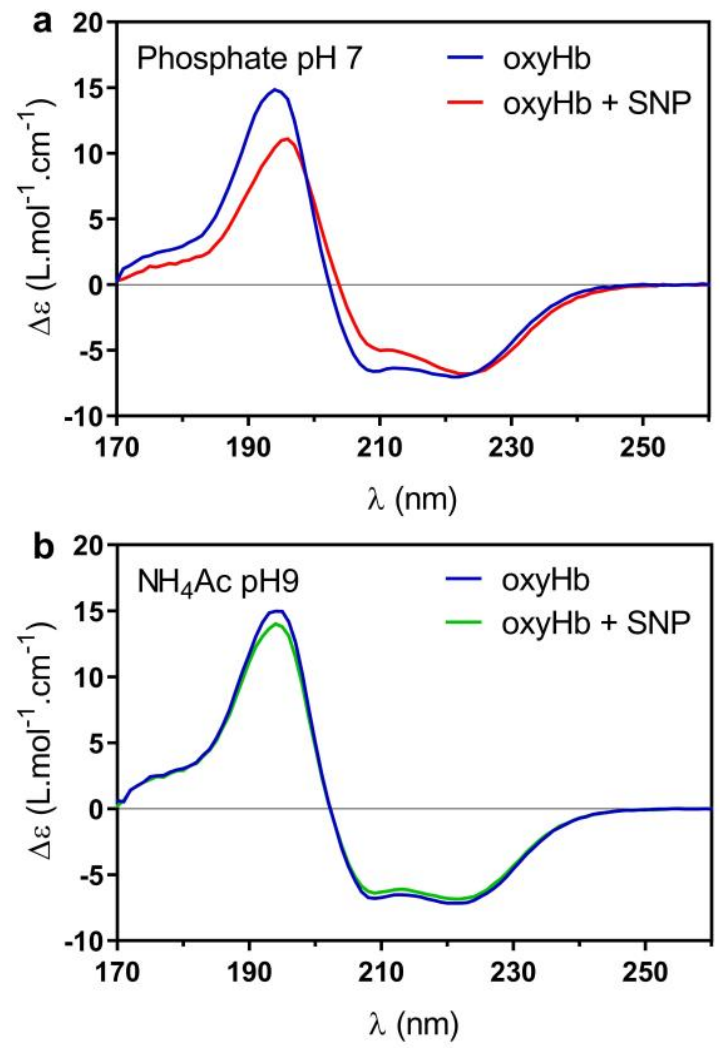

Figure 3. SRCD spectra of oxyHb with and without SNPs at $22^{\circ} \mathrm{C}$ (a) in phosphate buffer $\mathrm{pH} 7$ and (b) in $\mathrm{NH}_{4}$ Ac buffer $\mathrm{pH}$ 9. $\mathrm{C}($ oxyHb $)=1 \mathrm{mM}, \mathrm{C}(\mathrm{SNP})=100 \mathrm{mg} / \mathrm{mL}$.
The secondary structure of oxyHb was determined by deconvolution of the SRCD spectra with the BeStSel algorithm, showing good consistency between the experimental and the deconvoluted spectra (Figure $\left.\mathrm{S}_{4}\right) .{ }^{42,43}$ The structural analysis of oxyHb in solution was validated by comparing our results to the secondary structure calculated with DSSP for the crystal structure of porcine oxy $\mathrm{Hb}$ 1QPW.pdb (Table S2). The DSSP program calculates the secondary structure of a protein from the atomic coordinates of its crystal structure.44,45 Good agreement was observed between DSSP calculation and SRCD spectra deconvolution.

The differences between the SRCD spectra of oxyHb with and without SNPs at $\mathrm{pH} 7$ (Figure $3 \mathrm{a}$ ) reflect the structural changes induced by the formation of the hard corona. The spectrum of adsorbed oxyHb is characterized by a decrease of the intensity at 209 and $194 \mathrm{~nm}$, a shift of the maximum from $194 \mathrm{~nm}$ to $196 \mathrm{~nm}$, whereas the peak at $222 \mathrm{~nm}$ is unaffected. The structural analysis reveals a relatively limited decrease of the helix content from $68 \%$ to $59 \%$ following adsorption. The $\Delta \varepsilon(222 \mathrm{~nm}) / \Delta \varepsilon(209 \mathrm{~nm})$ ratio (corresponding to the two minima of the SRCD spectra of oxyHb) is equal to 1.04 for free oxyHb and increases to 1.38 for adsorbed oxyHb at $\mathrm{pH} 7$. This ratio is indicative of the intraand inter-molecular interactions between helices in oligomeric proteins. ${ }^{46} \mathrm{MD}$ simulations carried out by Jiang et al. on tetrameric hemoglobin suggest that the electronic transition at $208 \mathrm{~nm}$ is stronger at helix termini due to the parallel orientation of the polarisation to the helix axis, whereas the electronic transition at $222 \mathrm{~nm}$ is homogeneously distributed within the protein structure, with a polarisation perpendicular to the helix axis. ${ }^{47}$ The decrease of the ellipticity of adsorbed oxyHb at $209 \mathrm{~nm}$ and the unchanged ellipticity at $222 \mathrm{~nm}$ could suggest preferential alteration or reorientation of helix termini following adsorption on SNPs. Differential structural modifications between the $\alpha$ and $\beta$ subunits following adsorption could, for example, play a role.

At $\mathrm{pH}$ 9, we did not observe any differences between the SRCD spectra of oxyHb with and without SNPs at $22^{\circ} \mathrm{C}$ in $\mathrm{NH}_{4}$ Ac buffer (Figure 3 b) or in CHES buffer (Figure $\mathrm{S}_{4}$ ). Therefore there is no effect of SNPs on the secondary structure of weakly bound oxyHb forming the soft corona at $22^{\circ} \mathrm{C}$. This result also confirms that there is no artefact due to light scattering by SNPs on the SRCD spectrum of proteins in the far UV range.

Then, we investigated the effect of SNPs on the structure and stability of oxyHb in the hard and soft corona during thermal unfolding. We measured the SRCD spectra of ox$\mathrm{yHb}$ with and without SNPs at $\mathrm{pH} 7$ and at $\mathrm{pH} 9$ from $22^{\circ} \mathrm{C}$ to $97^{\circ} \mathrm{C}$ (Figure 4 , Figure $\mathrm{S}_{5}$ ). The melting curves are displayed as $\Delta \varepsilon(194 \mathrm{~nm})=\mathrm{f}(\mathrm{T})$ to compare the unfolding pathways of oxyHb with and without SNPs (Figure 5a). The thermal unfolding of oxyHb is characterized by a moderate decrease of the ellipticity between $20^{\circ} \mathrm{C}$ and $60^{\circ} \mathrm{C}$ followed by a sharp decrease between $60^{\circ} \mathrm{C}$ and $85^{\circ} \mathrm{C}$. The melting curves were best fitted by two-sigmoidal curves (Table 1). 

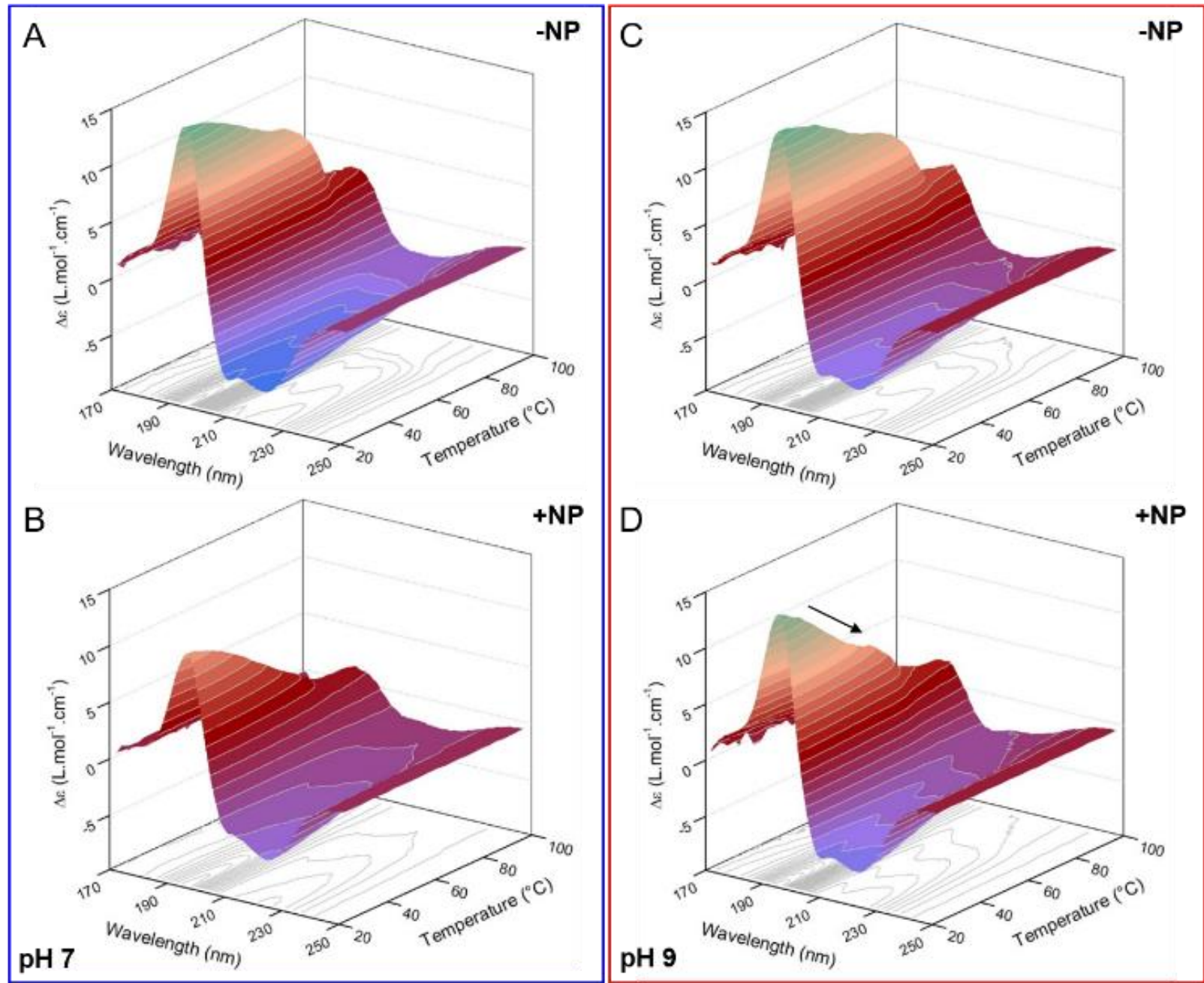

Figure 4. Thermal unfolding of oxyHb with and without SNPs $(\mathrm{A}, \mathrm{B})$ in phosphate buffer $\mathrm{pH} 7$, $(\mathrm{C}, \mathrm{D})$ in $\mathrm{NH}_{4} \mathrm{Ac}$ buffer $\mathrm{pH}$ 9. The SRCD spectra were recorded from $22^{\circ} \mathrm{C}$ to $97^{\circ} \mathrm{C}$. The arrow in D highlights the difference between the SRCD spectra of oxyHb with and without SNPs around physiological temperature at $\mathrm{pH} 9$.

The first phase centered on $\mathrm{T}_{\mathrm{m} 1}=47.0 \pm 0.6^{\circ} \mathrm{C}$ corresponds to the initiation of oxyHb unfolding at moderate temperature. It is followed by irreversible unfolding during the second phase centered on $\mathrm{T}_{\mathrm{m} 2}=77.4 \pm 0.5{ }^{\circ} \mathrm{C}$. Similar results were obtained by fitting the melting curves $\Delta \varepsilon(222 \mathrm{~nm})=$ $\mathrm{f}(\mathrm{T})$ showing good consistency in the analysis of the different polypeptide backbone electronic transitions of the SRCD spectrum (Figure S6, Table S3). The melting curves of oxyHb are very similar in phosphate buffer at $\mathrm{pH} 7$, in $\mathrm{NH}_{4}$ Ac buffer at $\mathrm{pH} 9$ and in CHES buffer at $\mathrm{pH}$ 9. The close values of the melting temperatures of oxyHb at $\mathrm{pH} 7$ and at $\mathrm{pH} 9$ suggest that the unfolding pathway of oxyHb is similar in both $\mathrm{pH}$ conditions (Table 1 ).

This two-step process was also observed by Yan et al. using 2D FTIR spectroscopy to follow the unfolding and the aggregation of hemoglobin with temperature. ${ }^{48}$ The authors describe $\mathrm{Hb}$ thermal unfolding as a two-phase process with an initial structural perturbation stage $\left(30^{\circ} \mathrm{C} \sim 50^{\circ} \mathrm{C}\right)$ characterized by the partial unfolding of the $\alpha$-helices associated with higher solvent exposure; and a thermal aggregation stage $\left(50^{\circ} \mathrm{C} \sim 80^{\circ} \mathrm{C}\right)$ dominated by the unfolding of buried structures and the formation of aggregates.
Table 1. Melting temperatures $\mathrm{T}_{\mathrm{m}}$ of oxyHb with and without SNPs obtained by fitting the melting curves $\Delta \varepsilon(194 \mathrm{~nm})=\mathrm{f}(\mathrm{T})$ with one $\left({ }^{*}\right)$ or two sigmoids. The experimental error related to the temperature measurement $\left(0.1{ }^{\circ} \mathrm{C}\right)$ was added to the curve fitting error.

\begin{tabular}{llll}
\hline Buffer & oxyHb $\pm \mathrm{SNP}$ & $\mathrm{T}_{\mathrm{m} 1}\left({ }^{\circ} \mathrm{C}\right)$ & $\mathrm{T}_{\mathrm{m} 2}\left({ }^{\circ} \mathrm{C}\right)$ \\
\hline Phosphate $\mathrm{pH} 7$ & oxyHb & $47.0 \pm 0.6$ & $76.0 \pm 0.4$ \\
& oxyHb + SNP & - & $57.0 \pm 0.7^{*}$ \\
$\mathrm{NH}_{4} \mathrm{Ac} \mathrm{pH} \mathrm{9}$ & oxyHb & $46.3 \pm 0.6$ & $77.4 \pm 0.5$ \\
& oxyHb + SNP & $41.7 \pm 0.4$ & $70.2 \pm 0.7$ \\
CHES pH 9 & oxyHb & $50.4 \pm 1.2$ & $79.1 \pm 0.7$ \\
& oxyHb + SNP & $41.2 \pm 0.5$ & $70.6 \pm 0.6$ \\
\hline
\end{tabular}

The structural analysis of the SRCD spectra supports this sequence of events (Figure $5 \mathrm{~b}$ ). We observed a first unfolding phase $\left(20^{\circ} \mathrm{C} \sim 60^{\circ} \mathrm{C}\right)$ characterized by a moderate decrease of the helical content and an increase of the disordered content of oxyHb (included in the 'others' section), and a second phase $\left(60^{\circ} \mathrm{C} \sim 80^{\circ} \mathrm{C}\right)$ wherein a larger portion 


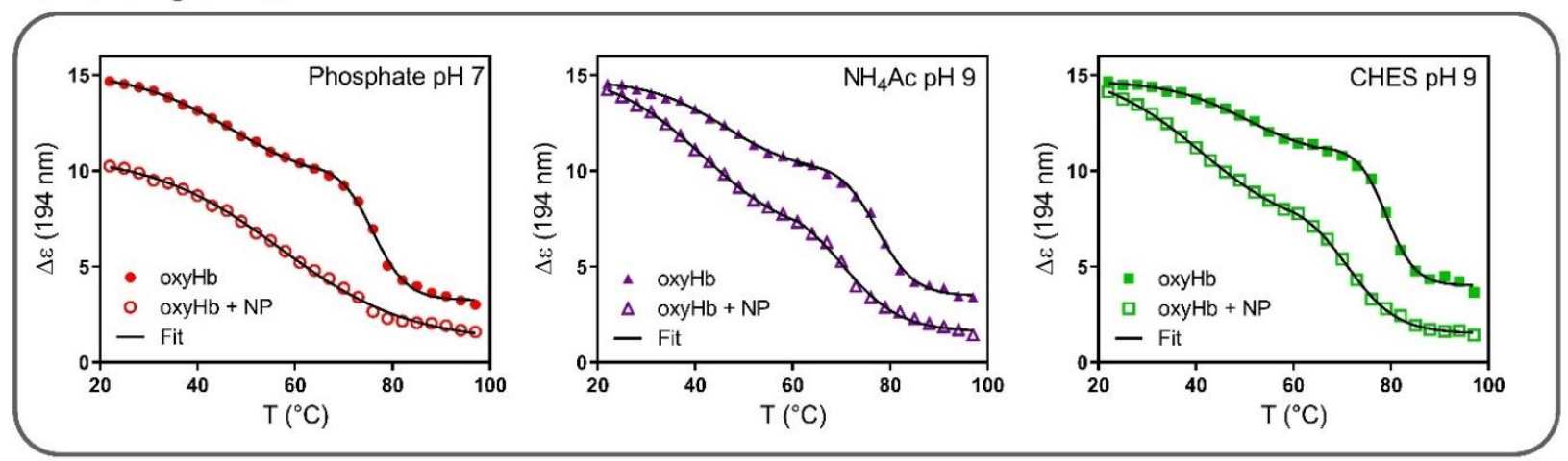

\section{B. Secondary structure deconvolution}
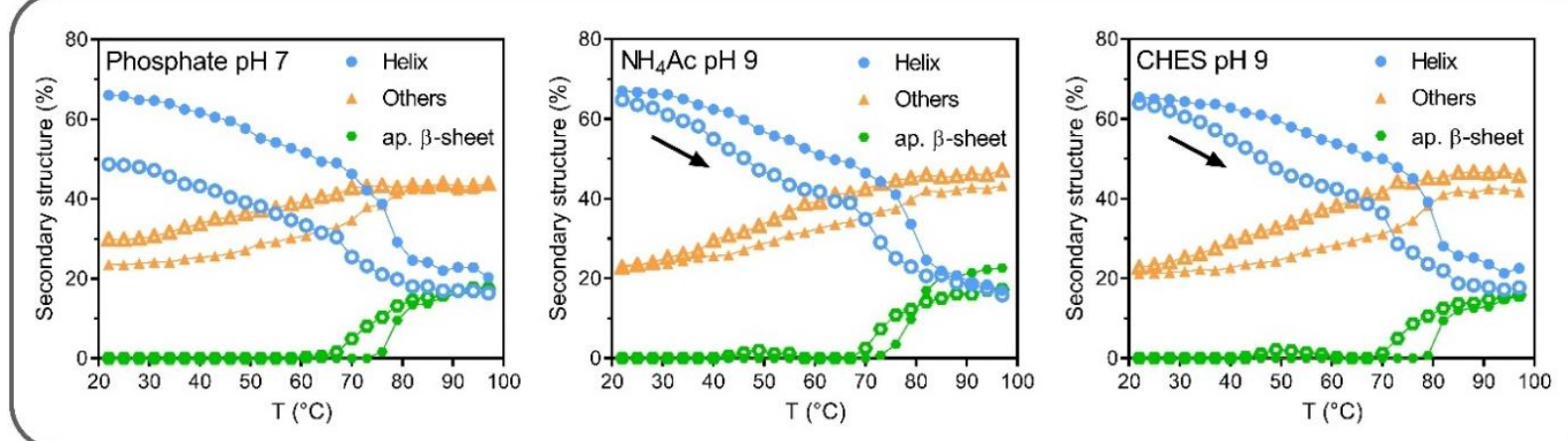

Figure 5. (A) Melting curves of oxyHb with and without SNPs expressed as $\Delta \varepsilon(194 \mathrm{~nm})$ in phosphate buffer $\mathrm{pH}$, in $\mathrm{NH}_{4} \mathrm{Ac}_{\text {buffer }}$ $\mathrm{pH} 9$ and in CHES buffer $\mathrm{pH}$ 9. Curves are fitted with two-sigmoids, except for oxyHb with SNPs at $\mathrm{pH} 7$, which is best fitted with one sigmoid. (B) Evolution of the helix, the antiparallel $\beta$-sheet (ap. $\beta$-sheet) content and 'others' (which includes the disordered fraction) of oxyHb with SNPs (open symbols) and without SNPs (closed symbols). Turns which show only minor changes and represent $<10 \%$ of the secondary structure (Table $\mathrm{S} 1$ ) are not included in the figure for clarity. The arrows highlight the partial loss of helices in oxyHb with SNPs at physiological temperature at $\mathrm{pH} 9$.

of the helices are unfolded and antiparallel $\beta$-sheets are formed. Since oxyHb does not contain any $\beta$-sheet in its native structure, we assume that the antiparallel $\beta$-sheets formed at high temperature correspond to intermolecular $\beta$-sheets associated with protein aggregation. ${ }^{8}$ The observation of the aggregation of free oxyHb by UV-vis spectroscopy at $60^{\circ} \mathrm{C}$ supports this hypothesis (data not shown).

Interestingly, a single-step process best describes the unfolding pathway of adsorbed oxyHb in the hard corona at $\mathrm{pH}$ 7. The melting curve $\Delta \varepsilon(194 \mathrm{~nm})=\mathrm{f}(\mathrm{T})$ is fitted by one sigmoidal curve centered on $\mathrm{T}_{\mathrm{m} 2}=57.0 \pm 0.7^{\circ} \mathrm{C}$ (Figure ${ }_{5} \mathrm{~A}$ ). The large decrease of the melting temperature shows that the adsorption of oxyHb on SNPs greatly impairs the thermal stability of the protein. This effect can be rationalized by the partial structural loss associated with the initial adsorption step which further reduces the enthalpic cost of protein unfolding with temperature. ${ }^{12,49,50}$

\section{SNPs alter the stability of weakly-bound proteins}

At $\mathrm{pH}$ 9, the evolution of the SRCD spectra of weaklybound oxyHb forming the soft corona revealed a completely different picture. Similarly to the thermal unfolding of free oxyHb, a two-step unfolding pathway is maintained. However, we observed a larger decrease of $\Delta \varepsilon(194 \mathrm{~nm})$ with
SNPs which gradually builds up with temperature. Identical effects were observed for oxyHb unfolding with SNPs in $\mathrm{NH}_{4} \mathrm{Ac}$ and in CHES buffers. The structural analysis shows that SNPs induce a partial loss of the helical structure of oxyHb and an increase of the disordered structure at moderate temperature (Figure $5 \mathrm{~B}$ ). At $40^{\circ} \mathrm{C}$, the helical content decreases to $55 \%$ in both buffer conditions (Table 2). Moreover, the decrease of $\mathrm{T}_{\mathrm{m}_{1}}$ and $\mathrm{T}_{\mathrm{m}_{2}}$ suggests that SNPs undermine the thermal stability of oxyHb at $\mathrm{pH} 9$ both at moderate and high temperature.

Table 2. Percentage of oxyHb adsorbed on SNPs (top line) and difference in the helical content of oxyHb with and without SNPs (below, in italics) at $22^{\circ} \mathrm{C}, 40^{\circ} \mathrm{C}, 50^{\circ} \mathrm{C}$ in phosphate buffer $\mathrm{pH}$, in $\mathrm{NH}_{4} \mathrm{Ac}$ buffer $\mathrm{pH}$ 9, and in CHES buffer $\mathrm{pH}$ 9. ${ }^{*} \mathrm{At} 5 \mathrm{O}^{\circ} \mathrm{C}$, oxyHb starts aggregating in solution.

\begin{tabular}{llll}
\hline $\mathrm{T}\left({ }^{\circ} \mathrm{C}\right)$ & Phosphate $\mathrm{pH}_{7}$ & $\mathrm{NH}_{4} \mathrm{Ac} \mathrm{pH} 9$ & $\mathrm{CHES} \mathrm{pH} 9$ \\
\hline 22 & $91.2 \pm 0.2 \%$ & $<3 \%$ & $<3 \%$ \\
& $-17.3 \%$ & $-2.3 \%$ & $-1.6 \%$ \\
40 & $87.7 \pm 1.1 \%$ & $<3 \%$ & $<3 \%$ \\
& $-18.4 \%$ & $-7.5 \%$ & $-8.0 \%$ \\
50 & & & \\
& & & \\
& & & \\
& $-18.7 \pm 0.7 \%$ & $<12.2 \pm 3.9 \%$ & $<7.0 \pm 3.7 \%$ \\
\hline
\end{tabular}


We focused our analysis on the moderate temperature range $\left(20^{\circ} \mathrm{C}-49^{\circ} \mathrm{C}\right)$ to investigate the destabilization effect of SNPs on oxyHb within the hard or soft corona before the initiation of aggregation. The SRCD spectra of oxyHb with and without SNPs at $22^{\circ} \mathrm{C}, 37^{\circ} \mathrm{C}$ and $49^{\circ} \mathrm{C}$ are shown in Figure $\mathrm{S}_{7}$. We can see that the secondary structure of oxyHb is already altered by SNPs at $\mathrm{pH} 9$ at physiological temperature with an additional loss of $8 \%$ of the helix content in the presence of SNPs. These results show that SNPs mediate the destabilization of weakly bound oxyHb within the soft corona at physiological temperature.

We observed that SNPs alter oxyHb secondary structure for $\mathrm{T}>30^{\circ} \mathrm{C}$. To check whether this effect could be due to the formation of a hard corona at higher temperature, we measured the amount of oxyHb adsorbed on SNPs from $22^{\circ} \mathrm{C}$ to $50^{\circ} \mathrm{C}$ (Table 2). Less than $3 \%$ of oxyHb adsorbs on SNPs at $40^{\circ} \mathrm{C}$, at $\mathrm{pH} 9$ in $\mathrm{NH}_{4} \mathrm{Ac}$ buffer and in CHES buffer, while an additional loss of $8 \%$ of the helical content is observed within oxyHb structure. This result shows that SNPs can destabilize oxyHb at moderate temperature even in the soft corona. At $50^{\circ} \mathrm{C}$, only $10 \%$ oxyHb remains adsorbed on SNPs after NP separation. Adsorption could be favoured by partial unfolding of oxyHb at this temperature. However protein unfolding also leads to the onset of aggregation of the free oxyHb in solution. As the amount of adsorbed ox$\mathrm{yHb}$ is measured by the depletion method after centrifugation of SNPs, the aggregation of oxyHb could artificially increase this value. This hypothesis is supported by the concomitant decrease of the amount of adsorbed oxyHb on SNPs at $\mathrm{pH} 7$.

OxyHb is neutral around $\mathrm{pH} 7$ ( $\mathrm{pI}=7.2$ for porcine ox$\left.\mathrm{yHb}^{51}\right)$ and globally negatively charged at $\mathrm{pH}$, whereas the SNPs are negatively charged at $\mathrm{pH} 7$ and at $\mathrm{pH} 9$ with similar surface charge in the 3 buffer conditions. Ionic strength can modulate protein adsorption on SNPs, ${ }^{50,52}$ but we did not observe differences between $\mathrm{NH}_{4} \mathrm{Ac}$ and CHES buffer at $\mathrm{pH}$ 9. The formation of a hard or soft corona of oxyHb on SNPs at $\mathrm{pH} 7$ and at $\mathrm{pH} 9$ respectively could primarily be explained by the difference in protein charge. Besides, the secondary structure of oxyHb is very similar in phosphate buffer $\mathrm{pH}$ 7, in $\mathrm{NH}_{4} \mathrm{Ac}$ buffer $\mathrm{pH} 9$ and in CHES buffer $\mathrm{pH} 9$ at $22^{\circ} \mathrm{C}$. Therefore we hypothesize that the change of oxyHb affinity for SNPs from $\mathrm{pH} 7$ (high affinity) to $\mathrm{pH} 9$ (low affinity) is mostly due to the deprotonation of basic residues in this $\mathrm{pH}$ range and to the electrostatic repulsion between negatively charged oxyHb and the anionic siloxide groups at the surface of SNPs. ${ }^{13,14,52}$

\section{Molecular basis of soft corona formation}

To gain insights into the structural changes of oxyHb as a function of $\mathrm{pH}$ and temperature, we performed molecular dynamic (MD) simulations of the oxyHb structure at $\mathrm{pH} 7$ and at $\mathrm{pH} 9$ at $295 \mathrm{~K}\left(22^{\circ} \mathrm{C}\right), 322 \mathrm{~K}\left(49^{\circ} \mathrm{C}\right), 353 \mathrm{~K}\left(80^{\circ} \mathrm{C}\right)$ and $400 \mathrm{~K}\left(127^{\circ} \mathrm{C}\right)$ (Figure 6). As charge plays a key role in protein-NP interactions in our system, first we calculated the protonation state of oxyHb at $\mathrm{pH} 7$ and at $\mathrm{pH}$ 9. Each ox$\mathrm{yHb} \alpha$ and $\beta$ chain contains 3 Arg, 11 Lys, 11 His, and 5 Arg, 11 Lys, 8 His respectively. His side chain has a pKa around 6. Three protonation states of His were considered: HID,
HIE, and HIP, which correspond to the protonation of only ND1 (HID), only ND2 (HIE), or both ND1 and ND2 (HIP) (Figure S8). At $\mathrm{pH}$ 9, His is neutral and can only adopt one of the two tautomer forms, HID or HIE. At $\mathrm{pH} 7$, His can also be in the protonated HIP form and carry a global charge of +1 . We used two independent programs, Protoss 53,54 and Propka ${ }^{55,56}$, to evaluate the protonation state of His in oxyHb structure at $\mathrm{pH} 7$ and at $\mathrm{pH} 9$ (see Methods).

Among the 38 His residues, only 3 were predicted to be protonated: His5o, His112 in $\alpha$ subunit, and His12o in $\beta$ subunit. Accordingly we assigned the HIP form (charge +1 ) to these $3 \mathrm{His}$ at $\mathrm{pH}$ 7. For the other His residues, we assigned the tautomer form (HIE or HID) predicted by Propka 3.1 in the presence of ligands (Table $\mathrm{S}_{4}$ ). This program checks the local environment of each His to predict the tautomer form which is most likely.

We followed the same approach to define the protonation state of His residues in oxyHb structure at $\mathrm{pH}$ 9. In this case, only HID and HIE protonation states were considered (Figure S9). After assigning the calculated His protonation state to oxyHb structure at $\mathrm{pH} 7$ and $\mathrm{pH}$ 9, we simulated the evolution of the protein structure in both $\mathrm{pH}$ conditions at 4 different temperatures by MD simulation (Figure 6). The fluctuations which appear on the RMSF (Root Mean Square Fluctuations) graphs are reported on the ${ }_{3} \mathrm{D}$ structure of oxyHb. The most mobile regions (in red) are visible in the protein structure. When temperature increases, the regions showing the largest fluctuations remain the same. The existing mobile substructures become larger, without any appearance of new mobile element.

Note that the simulation at $400 \mathrm{~K}$ is used here to emphasize the fluctuations in the protein structure and to check whether new mobile elements appear at high temperature. MD simulations minimize protein unfolding, that is structural modifications are usually underestimated at the target temperature, unless much longer simulation times are used. ${ }^{7}$ This explains why the simulated structure appears relatively preserved at a target temperature above the real unfolding temperature of oxyHb.

The most mobile regions are similar at $\mathrm{pH} 7$ and $\mathrm{pH}$ 9. Interestingly, the intensities of the fluctuations are more homogeneous within the oxyHb structure at $\mathrm{pH} 7$. For the 2 systems, 2 regions are particularly altered with temperature: the helix-loop-helix motif (residues 43 to 56 in $\alpha$ subunit), and the helix motif (residues 218 to 236 in $\beta$ subunit). Even if the amino acid sequences of $\alpha$ and $\beta$ subunits differ, their folding is the same.

The structures of these 2 motifs are shown at $295 \mathrm{~K}, 322 \mathrm{~K}$, and $400 \mathrm{~K}$ in Figure 6. We can see that the hydrogen bond between Asn 47 and Ser52 that closes the loop is broken at high temperature in the helix-loop-helix structure. Polar amino acids become exposed, in particular Ser49, Ser51, and His5o, which is protonated at $\mathrm{pH}$ 7. These residues can then interact with a ligand through molecular interactions. This mechanism is also reflected by the decrease of the percentage of $\mathrm{H}$ bonds within this motif when temperature increases. The secondary structure of the second helix motif 

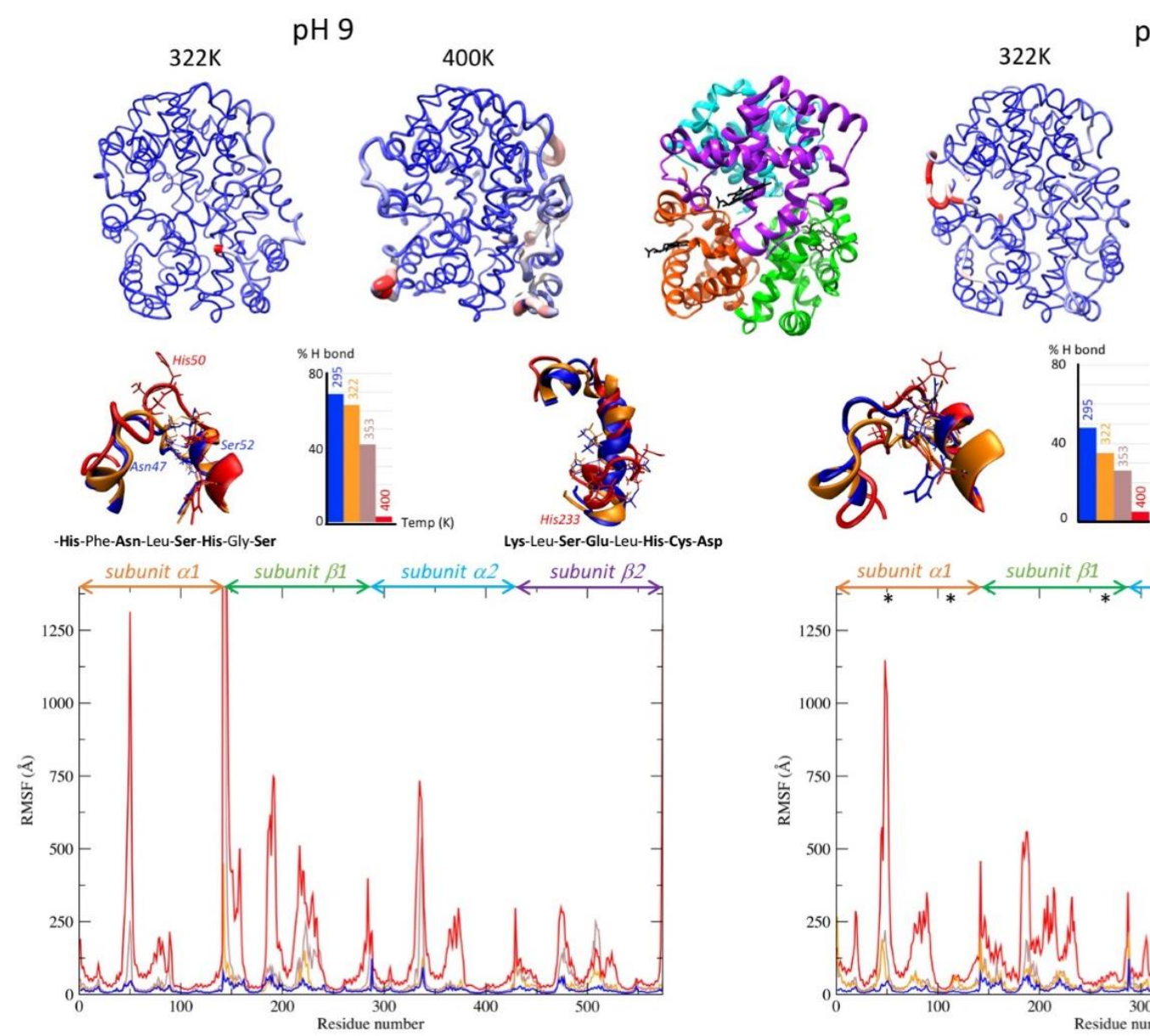

$\mathrm{pH} 7$
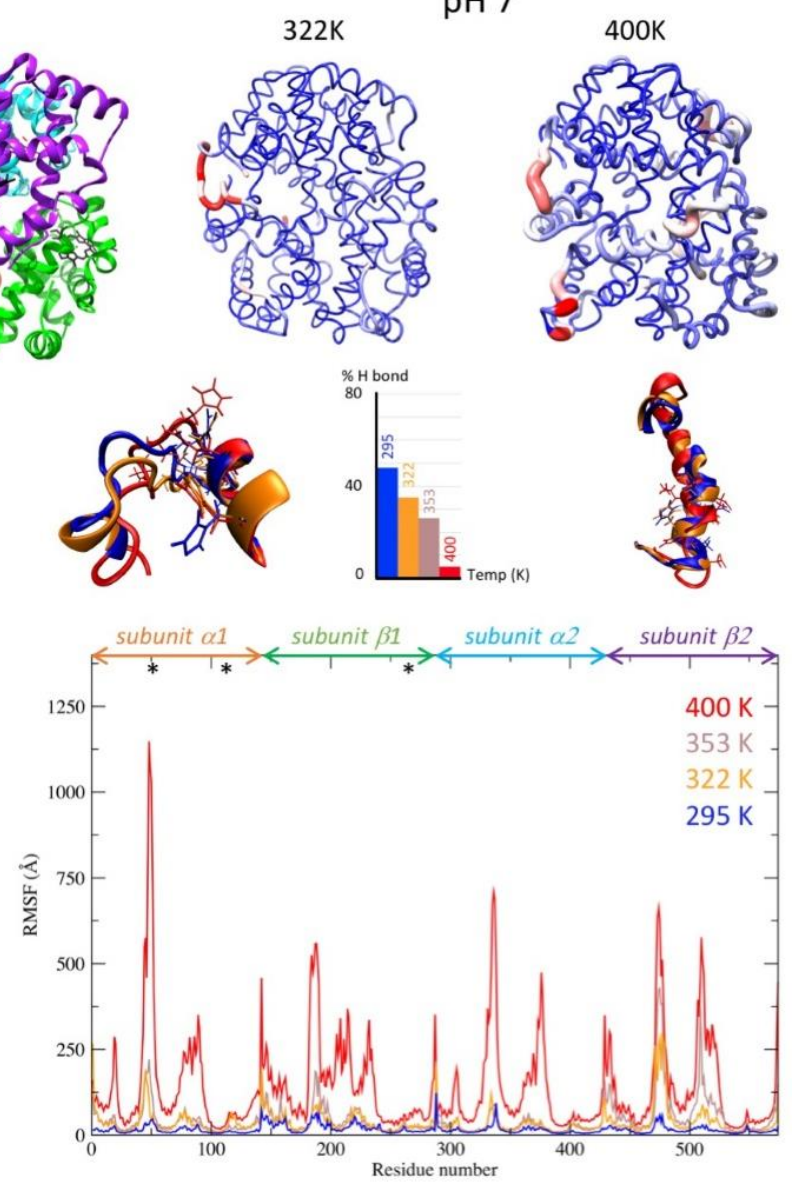

Figure 6. MD simulations of oxyHb structure at $\mathbf{p H} 7$ and $\mathbf{p H} 9$ as a function of temperature. Structures obtained at the end of the simulation at $322 \mathrm{~K}$ and $400 \mathrm{~K}$ are represented at the top (at $\mathrm{pH} 9$ on the left, at $\mathrm{pH} 7$ on the right) and coloured according to the RMSF of each residue (small fluctuations in blue, large fluctuations in red). The same colour gradient was applied to all the structures. Each subunit of the tetrameric structure is represented in cartoon mode in a different colour at the top centre of the figure with the 4 hemes represented in black licorice mode. The limits between each subunit are reported on the RMSF graphs below. The RMSF of the backbone atoms is shown along oxyHb sequence at $295 \mathrm{~K}$ (blue), $322 \mathrm{~K}$ (orange), $353 \mathrm{~K}$ (brown), and $400 \mathrm{~K}$ (red). * indicates HIP histidine with a +1 charge at $\mathrm{pH} 7$. The inset structures represent the helix-turn-helix motif centered on His5o and the helix motif from Leu222 and Asp235, at $295 \mathrm{~K}, 322 \mathrm{~K}$, and $400 \mathrm{~K}$. The corresponding sequences of the turn and helix motifs that break with temperature are displayed. Polar or charged residues area highlighted in bold. The histogram represents the percentage of hydrogen bonds between Asn 47 and Ser52 closing the turn at each temperature.

is totally ruptured at $353 \mathrm{~K}$. This also leads to the exposure of polar and charged residues, notably His233.

These results suggest that the exposure of polar and charged amino acids following the disruption of these 2 motifs with temperature, and in particular Asn47, Ser52, His 5o, and His233, may drive the interactions of oxyHb with SNPs. This hypothesis is supported by the increase in the surface accessibility of oxyHb with temperature at $\mathrm{pH}$ 7 and at $\mathrm{pH} 9$ (Figure 7a, Figure Sio), which could favour interactions with the silica surface. The increase in the solvent-accessible surface area (SASA) of oxyHb is explained here by two factors: -the increase in protein flexibility as expressed by its B-factor; -the loss of some structural elements exposing some residues to the solvent, such as the 2 motifs described here. The sequence 43-56, in particular, shows a marked increase in the residue SASA with temperature at $\mathrm{pH} 9$ (Figure $\mathrm{S}_{11}$ ).

To determine if this mobile region can interact with the silica surface, we calculated the interaction energy between the corresponding peptide and the silica surface.
The motif structures at 295 and at $400 \mathrm{~K}$ (hereafter called $\mathrm{P}_{2} 95$ and $\mathrm{P} 400$ ) were extracted from the MD simulation of the oxyHb structure (Figure 6). The peptide sequence is Phe43-Pro44-His45-Phe46-Asn47-Leu48-Ser49-His5o-

Gly51-Ser52-Asp53-Gln54-Val55-Lys56. The terminal -CO and $-\mathrm{NH}$ groups of the sequence were replaced by $\mathrm{H}$ atoms. The interaction of $\mathrm{P}_{2} 95$ and $\mathrm{P}_{4} 00$ with the silica surface was analyzed at the quantum chemistry level using the Dispersion-Corrected Self Consistent Charge Density Functional Tight Binding (DC-SCC-DFTB), which is an approximated DFT method adapted to the system size (445 atoms) $5^{8}$ The silica surface was represented by a silica slab of 17 x 17 x 5 A along the ool plane composed of $42 \mathrm{SiO}_{4}$ units with $68 \mathrm{OH}$ surface groups. The $\mathrm{N}$ and $\mathrm{C}$ atoms of the two first and last residues were frozen. The peptide was positioned $2 \AA$ away from the silica slab at the beginning of the calculation, with the most mobile region corresponding to residues 50-56 oriented towards the surface. The minimized structures of $\mathrm{P}_{295}$ and $\mathrm{P}_{4} 00$ in interaction with the silica surface are shown in Figure 7. 
a

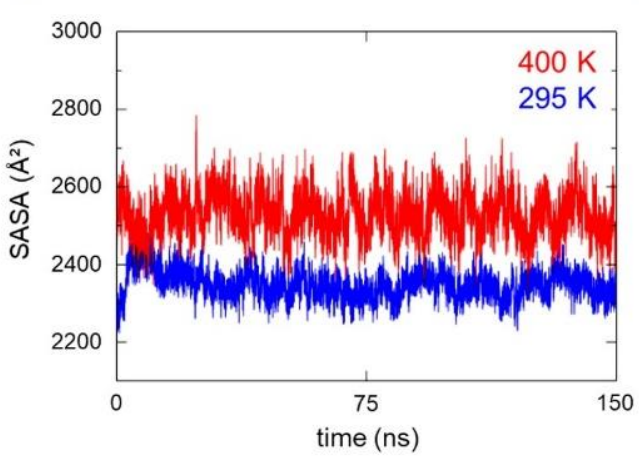

b

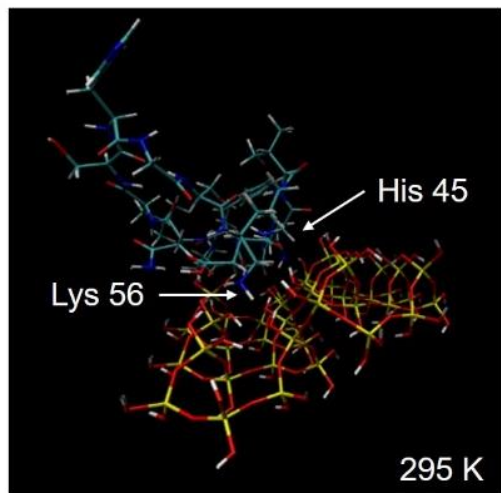

C

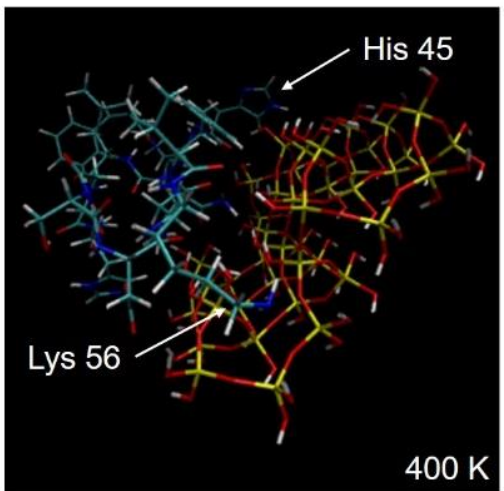

Figure 7. Surface accessibility of oxyHb and interaction of the mobile region with the silica surface at $\mathrm{pH} 9$ as a function of temperature. (a) Calculated solvent-accessible surface area (SASA) of oxyHb at pH 9 at $295 \mathrm{~K}$ (in blue) and at $400 \mathrm{~K}$ (in red). The calculation time is $150 \mathrm{~ns}$. (b,c) DC-SCC-DFTB calculations of the interaction of peptide 43-56 with the silica surface starting from the structure at $295 \mathrm{~K}$ (b) and from the structure at $400 \mathrm{~K}$ (c). The peptide sequence is Phe43-Pro44-His45-Phe46-Asn47Leu48-Ser49-His5o-Gly51-Ser52-Asp53-Gln54-Val55-Lys56. The peptide structure was extracted from MD simulation of oxyHb structure at $\mathrm{pH} 9$ at $295 \mathrm{~K}$ and $400 \mathrm{~K}$ respectively. Residues Lys 56 and His 45 are shown by white arrows in the minimized structure. The silica surface is represented by a silica slab of $17 \times 17$ × $5 \AA$ along the oo1 plane. The system is composed of 445 atoms with $\mathrm{Si}$ (yellow), O (red), H (white), C (grey), N (blue).

The interaction energy between $\mathrm{P}_{294}$ and $\mathrm{P}_{400}$ with the silica surface was calculated by subtracting the energy of the peptide and the silica slab alone minimized at the same level of theory. The interaction energy with the silica surface was $-3.3 \mathrm{eV}$ for $\mathrm{P}_{295}$ and $-4.2 \mathrm{eV}$ for P400. This result shows that the interaction with the silica surface is much more favourable for the denatured peptide.

The positioning of $\mathrm{P}_{2} 95$ and $\mathrm{P}_{4} 00$ on the silica surface (Figures $7 \mathrm{~b}$ and $7 \mathrm{c}$ ) suggests that this favourable interaction comes from a larger contact area of the denatured peptide with the surface, compared with the native peptide. Interestingly, the interaction with the silanol groups does not derive solely from basic amino acids (here Lys56, His45), but also from the carbonyl group of the peptide bond.

To test if the increase in the contact area between the peptide and silica was responsible for the favourable interaction, we calculated the interaction energy of $\mathrm{P}_{295}$ and $\mathrm{P} 400$ with a silica cluster composed of $20 \mathrm{SiO}_{4}$ units that provides a more limited surface area (average diameter $7 \AA$ (Figure S12). The same parameters and initial position of the peptides were applied. In this case, similar interaction energies were calculated for $\mathrm{P}_{2} 95$ and $\mathrm{P}_{400}(-0.58 \mathrm{eV}$ for $\mathrm{P}_{295}$ and $-0.59 \mathrm{eV}$ for P400). These data confirm that the higher interaction energy of $\mathrm{P}_{400}$ with the silica surface is not due to stronger interactions of individual amino acids, but to a higher number of interactions or "contact points". We conclude that the increase in surface accessibility and the partially unfolded state of this motif favours its interaction with the silica surface.

We observed that partial unfolding of oxyHb with temperature favours the interactions of weakly bound proteins with SNPs at $\mathrm{pH}$ 9, as shown by the destabilization effect observed by SRCD. A lower number of "contact points" (e.g. following His exposure with temperature) could account for the weak interaction between oxyHb and SNPs at $\mathrm{pH} 9$ leading to the formation of a soft corona, as opposed to $\mathrm{pH} 7$ where strong adsorption occurs at $22^{\circ} \mathrm{C}$ between native oxyHb and SNPs.
More generally, the folded structure of a protein results from the equilibrium between stabilizing and destabilizing forces, such as the formation of non-covalent interactions and the entropic contributions of both the protein and the solvent. However, the interplay of molecular forces that determine protein stability in solution may differ when a protein interacts with a surface. ${ }^{59}$ We observed nanoparticle-mediated destabilization of weakly-bound proteins at moderate temperature during the first phase of oxyHb unfolding, that is when an equilibrium is formed between folded and partially unfolded conformations. ${ }^{60}$ The intrinsic affinity of a protein for a surface is not a fixed parameter and changes in protein structure can initiate protein adsorption. For example, GFP (green fluorescent protein) does not exhibit any affinity for SNPs in its native form, and adsorbs spontaneously following protein unfolding. ${ }^{61}$ The conformational changes of Complement protein $C_{3}$ following its proteolytic activation promote the binding of the $\mathrm{C}_{3} \mathrm{~b}$ fragment to the surface of pathogens or nanomaterials which triggers the Complement cascade. ${ }^{62,63}$ It is also known that denatured proteins have a higher tendency to stick to surfaces. This effect is rationalized by the exposure of hydrophobic regions, the partial loss of structure and the higher flexibility of unfolded proteins that favour proteinsurface interactions. ${ }^{59}$

Interestingly, recent studies reported that even slight changes of the incubation temperature of NPs with plasma or serum alter the composition of the protein corona in the $20^{\circ} \mathrm{C}-50^{\circ} \mathrm{C}$ temperature range. ${ }^{64,65}$ Studies also reported a decreased affinity of some proteins for NPs at moderate temperature. ${ }^{66}$ These observations suggest that structural events predating irreversible protein unfolding can alter the adsorption profile of a protein in a temperature-dependent way within a complex biological medium composed of hundreds of different proteins such as human serum. However, the wider impact of moderate temperature on the protein-NP interactions and the associated structural changes remain unclear. 


\section{SNPs stabilize partially unfolded conformations}

We hypothesize that partially unfolded conformations of oxyHb exhibit a higher affinity for SNPs, which shifts the unfolded-folded equilibrium towards the unfolded state (Figure 8). The affinity of a protein for one NP is expressed by $K_{a d s}$ determined by fitting the adsorption isotherm of the protein with the Langmuir model (or other adsorption models). $K_{a d s}$ is calculated from the amount of adsorbed protein measured after NP separation from the biological medium. Therefore, $K_{a d s}$ only reflects the affinity of tightly bound high-affinity proteins forming the hard corona. This parameter does not take into account proteins weakly or transiently bound to NPs, which are lost during the separation step.

This concept is easily understood when one considers an assemblage of various proteins interacting with NPs. Here we suggest that a similar mechanism can drive protein-NP interaction wherein different conformational states in equilibrium exhibit different affinities for NPs. Our experimental results clearly show that SNPs destabilize oxyHb at $\mathrm{pH}$ 9. Because this interaction does not lead to the formation of a stable layer of adsorbed proteins on SNPs (hard corona), the classical approach based on NP separation from the biological medium fails to consider this mechanism. This is due in part to the low concentration of partially unfolded states which cannot be detected using classical methodologies.

The stability of each conformation is defined by its free energy $\Delta G(T)$. We determined the free energy of unfolding $\Delta \mathrm{G}_{\mathrm{u}}$ of oxyHb with and without SNPs to investigate the mechanisms leading to the destabilization of weakly bound proteins. The decrease of oxyHb stability can result either from a decrease of the enthalpy of unfolding $\left(\Delta \mathrm{H}_{\mathrm{u}}\right)$ or from an increase of the entropy of unfolding $\left(\Delta \mathrm{S}_{\mathrm{u}}\right)$ (eq. 3):

$$
\Delta G_{u}(T)=\Delta H_{u}-T \Delta S_{u}
$$

$\Delta \mathrm{H}_{\mathrm{u}}$ and $\Delta \mathrm{S}_{\mathrm{u}}$ are usually calculated using a two-state model $\mathrm{F} \leftrightarrow \mathrm{U}$ by applying the Van't Hoff law to the CD data on the full temperature range (assuming $\Delta C_{p}$ is constant) ${ }^{67}$ However, equilibrium thermodynamics analysis can be applied only if protein unfolding is reversible, which is no longer the case when protein aggregation occurs simultaneously. ${ }^{68}$ We saw that oxyHb thermal unfolding is characterized by two thermal transitions $\mathrm{T}_{\mathrm{m} 1}$ and $\mathrm{T}_{\mathrm{m} 2}$ associated to a first partial unfolding phase without aggregation $\left(20^{\circ} \mathrm{C}-50^{\circ} \mathrm{C}\right)$, and a second unfolding phase where aggregation and unfolding happens simultaneously $\left(50^{\circ} \mathrm{C}-80^{\circ} \mathrm{C}\right)$. We also showed that oxyHb does not form a hard corona on SNPs during the first unfolding phase at $\mathrm{pH}$ 9. Therefore, we focused our analysis on the first unfolding phase to determine the thermodynamic parameters of oxy $\mathrm{Hb}$ partial unfolding with and without SNPs before the initiation of aggregation, and close to physiological temperature.

We defined $\Delta \mathrm{G}_{\mathrm{u}}{ }^{\prime}, \Delta \mathrm{H}_{\mathrm{u}}{ }^{\prime}$ and $\Delta \mathrm{S}_{\mathrm{u}}$ ' as the equilibrium thermodynamic parameters associated with the partial unfolding of oxyHb during the first unfolding phase. The corresponding midpoint temperature of unfolding is $\mathrm{T}_{\mathrm{m} 1}$ so $\Delta \mathrm{G}_{\mathrm{u}}^{\mathrm{o}}{ }^{\prime}\left(\mathrm{T}_{\mathrm{m} 1}\right)$ $=\mathrm{o}$. The fraction of partially unfolded oxyHb $f(T)$ was calculated from the helix content of oxyHb A(T) (eq 4).

$$
f(T)=\frac{A_{n}-A(T)}{A_{n}-A_{u}}
$$

where $A(T)$ is the helix content of oxyHb as a function of temperature, $A_{n}$ the helix content of native oxyHb at $22^{\circ} \mathrm{C}$ and $\mathrm{A}_{\mathrm{u}}$ the helix content of partially unfolded oxyHb at the end of the first unfolding phase. The evolution of $f(T)$ is different with and without SNPs (Figure S13) and seems independent on the $\mathrm{pH}$ and buffer conditions. The constant of partial unfolding $\mathrm{K}_{\mathrm{u}}$ ' is defined as (eq 5):

$$
K_{u}{ }^{\prime}=\frac{f(T)}{1-f(T)}
$$

The thermodynamic parameters of oxyHb partial unfolding during the first unfolding phase were obtained by fitting $\mathrm{K}_{\mathrm{u}}{ }^{\prime}(\mathrm{T})$ with the Van't Hoff law (eq 6):

$$
\ln K_{u}{ }^{\prime}=-\frac{\Delta H_{u^{\prime}}}{R T}+\frac{\Delta S_{u^{\prime}}}{R}
$$

The Van't Hoff plots are shown in Figure S14. The thermodynamic parameters of oxyHb partial unfolding are summarized in Table S6. Then, the variation of $\Delta \mathrm{G}_{\mathrm{u}}{ }^{\prime}(\mathrm{T})$ was calculated for each condition (Figure $\mathrm{S}_{15}$ ). SNPs induce a decrease of $\Delta \mathrm{G}_{\mathrm{u}}{ }^{\prime}(\mathrm{T})$ of oxyHb at $\mathrm{pH} 9$ on the full temperature interval of the first unfolding phase, that is a decrease of protein stability. Based on the decrease of the melting temperature and the preferential interaction of unfolded proteins with SNPs (Figure 7c), ${ }^{61}$ we hypothesize that this reduction in stability (decrease of $\Delta \mathrm{G}_{\mathrm{u}}{ }^{\prime}(\mathrm{T})$ ) is associated with an enhanced stability of the partially unfolded conformations forming the soft corona (formally a decrease of the Gibbs energy of the unfolded state). ${ }^{69}$ The differences in enthalpy and entropy of oxyHb partial unfolding with and without SNPs were expressed as $\Delta \Delta \mathrm{H}_{\mathrm{u}}$ ' and $\Delta \Delta \mathrm{S}_{\mathrm{u}}{ }^{\prime}$ where $\Delta \Delta \mathrm{X}_{\mathrm{u}}{ }^{\prime}=\Delta \mathrm{X}_{\mathrm{u}}{ }^{\prime}\left(\right.$ oxyHb+SNP) $-\Delta \mathrm{X}_{\mathrm{u}}{ }^{\prime}($ oxyHb) for $\mathrm{X}=\mathrm{H}, \mathrm{S}$ (Table S7). In $\mathrm{NH}_{4}$ Ac buffer, both $\Delta \Delta \mathrm{H}_{\mathrm{u}}{ }^{\prime}$ and $\Delta \Delta \mathrm{S}_{\mathrm{u}}{ }^{\prime}$ are negative $\left(\Delta \Delta \mathrm{H}_{\mathrm{u}}{ }^{\prime}=-4.0 \mathrm{~kJ} \cdot \mathrm{mol}^{-1}, \Delta \Delta \mathrm{S}_{\mathrm{u}}{ }^{\prime}=-6.3 \mathrm{~J} \cdot \mathrm{mol}^{-1} \cdot \mathrm{K}^{-1}\right)$. These results show that the destabilization effect of SNPs on weaklybound proteins forming the soft corona is enthalpy-driven.

This analysis strongly supports our hypothesis that the destabilization effect of SNPs is due to molecular interactions that stabilize partially unfolded conformations in the soft corona and shift the folded $\leftrightarrow$ unfolded equilibrium towards the unfolded states (Figure 8). This effect primarily comes from the range of affinity of different protein conformations for the NP surface when weak protein-NP interactions take place. As temperature increases, molecular interactions between partially unfolded conformations and NPs potentiate oxyHb thermal unfolding.

The free energy of protein unfolding can be affected by a high concentration of macromolecules or solutes, such as polymers, sugars, or urea, which can stabilize or destabilize proteins by different mechanisms by excluded volume effect, preferential hydration, or preferential binding. ${ }^{70,71}$ Based on the analysis of ubiquitin unfolding, Senske et al. classified cosolute effects in terms of their enthalpic contribution to protein stability. $7^{\circ}$ According to this classification, a negative $\Delta \Delta \mathrm{H}_{\mathrm{u}}$ and a negative $\Delta \mathrm{T}_{\mathrm{m}}$ as observed for the unfolding of oxyHb with SNPs at $\mathrm{pH} 9$ is associated 

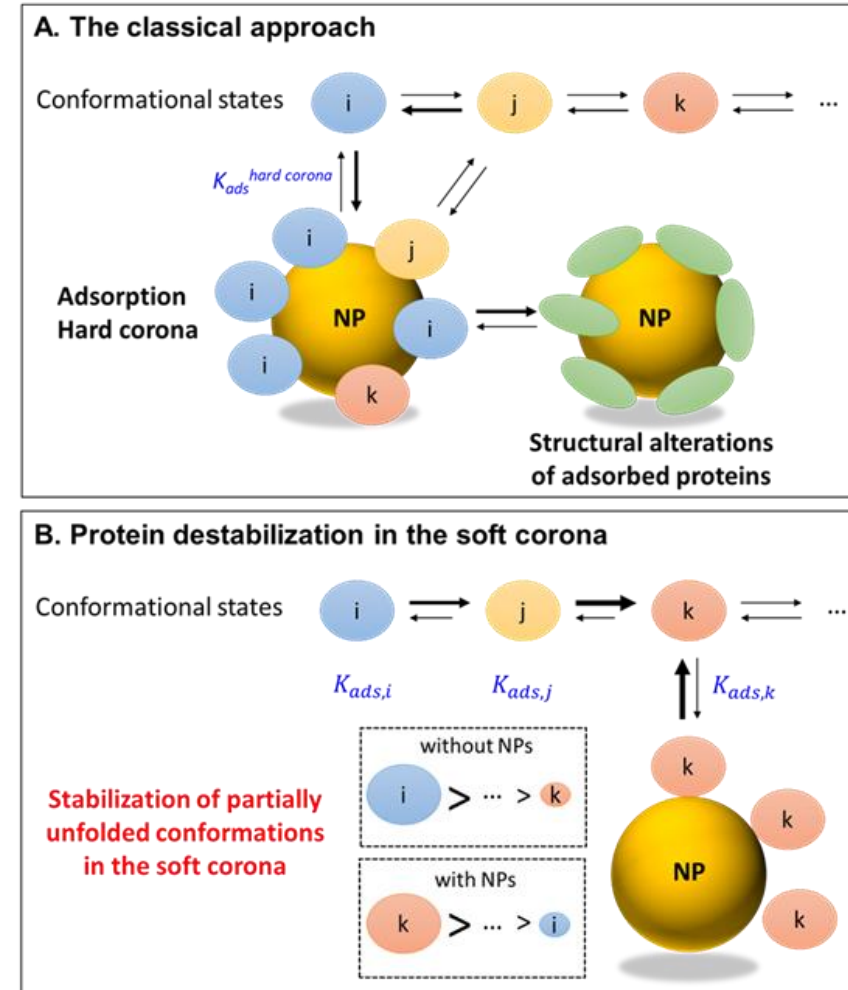

with preferential binding of the solute on the accessible protein surface..$^{70}$

The extent of the destabilizing effect of SNPs on oxyHb $\left(\Delta \Delta \mathrm{H}_{\mathrm{u}}{ }^{\prime}=-4.0 \mathrm{~kJ} . \mathrm{mol}^{-1}\right)$ is of the same order of magnitude (a few kJ.mol-1) as the data reported by Kumar et al. and Christiansen et al. for enthalpy-driven and entropy-driven macromolecular crowding effects respectively.71,72

Whether the destabilization effects of SNPs on oxyHb and the formation of the soft corona could be described as enthalpy-driven macromolecular crowding effect remains to be elucidated. However, we can advance that nanoparticles are as diverse as other solutes in terms of their effects on protein stabilization or destabilization. Indeed, if we measured here an enthalpic destabilization of weakly bound proteins, Ortega et al. observed an entropic stabilization of protein L covalently bound to a gold surface. 59

This study was carried out on a model protein to allow the in situ analysis of the structural modifications associated with soft corona formation. The structural analysis of multiple proteins in a biological environment remains challenging. Studies suggested that the composition of the hard and soft corona differ from each other in the biological medium. ${ }^{24,73}$ This observation shows that both strong and weak interactions will drive the formation of the biomolecular corona in vivo and highlights the potential effect of weak protein-surface interactions on the biological effects of nanomaterials in situ. ${ }^{74}$.

Finally, we discuss the effects of affinity changes on the evolution of the protein corona in biological environments. The driving force of the destabilization process observed here is the interaction of partially unfolded proteins with SNPs. Previously we observed that the exacerbated affinity of unfolded proteins for SNPs leads to their adsorption,
Adsorption isotherm after NP separation
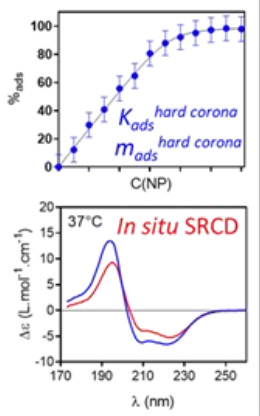

Adsorption isotherm after NP separation

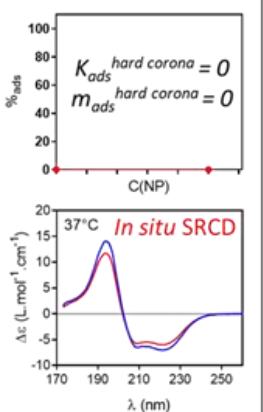

Figure 8. Nanoparticle-mediated protein destabilization. (A) In the classical approach, NPs are separated from the biological medium before protein analysis. The adsorption constant and the structural analysis of adsorbed proteins solely reflects the high affinity and the structural alterations of proteins forming the hard corona. (B) Destabilization of weakly-bound proteins in the soft corona. Nanoparticles stabilize partially unfolded conformations in the soft corona and shift the folded $\leftrightarrow$ unfolded equilibrium towards the unfolded states. Protein destabilization remains unseen in the classical approach, but is visible with in situ analytical techniques such as SRCD. Representative adsorption isotherms and SRCD spectra of ox$\mathrm{yHb}$ forming a hard corona (top panel) or a soft corona (bottom panel) are shown. The reference spectra of oxyHb without SNPs are shown in blue for each condition. even when SNPs are already covered by other proteins. ${ }^{61}$ The release of proteins from the hard corona shows that unfolded proteins displaced proteins that initially formed a stable corona. Furthermore, unfolded proteins accessed surface spaces that were completely inaccessible to folded ones. Therefore, unfolded proteins can directly interact with NP surface and reshuffle the hard corona, highlighting the role of protein-surface interactions in the dynamic steps of the protein corona formation in complex environments.

Protein-protein interactions can also take place, such as recognition of adsorbed unfolded proteins by chaperonins, ${ }^{61}$ showing that both protein-protein and proteinsurface interactions will contribute to shaping a constantly evolving corona.

Using Surface-Plasmon Resonance, Kari et al. analyzed the soft and hard protein corona formed on liposomes anchored on a gold surface by flushing human plasma first, followed by buffer..$^{73}$ Both a hard and a soft corona formed on all liposomes. The analysis of their composition for different liposome formulation revealed that numerous proteins were identified in the hard corona on some liposomes, whilst being found in the soft corona on others. This observation suggests that differences in protein-surface interactions, corresponding to differences in protein affinity, may explain their presence either in the hard or soft corona. These authors conclude that transient proteinsurface interactions contribute to the formation of the soft corona in human plasma.

Simon et al. showed that the evolution the protein corona in human serum, following changes in protein affinity as a function of temperature, critically affects NP cellular up- 
take. ${ }^{66}$ Therefore, a change in protein affinity for NP induced by structural modifications, which we recorded here in a model protein by SRCD and MD simulation, may contribute to the constant reshuffling of the protein corona in a biological environment, where weak protein-surface interactions play a role in NP-cell interactions.

\section{CONCLUSION}

Using cryoTEM and SRCD, we show that NPs alter the structure and the stability of weakly bound proteins in situ. MD simulation identified the molecular bases driving the formation of the soft corona. Based on thermodynamic analysis, we show that NPs stabilize partially unfolded protein conformations in the soft corona by enthalpy-driven molecular interactions. We suggest that NPs alter weakly bound proteins by shifting the equilibrium towards the unfolded states at physiological temperature. We show that the classical approach based on NP separation from the biological medium fails to detect this effect and therefore cannot be used to fully predict the biological effects of nanomaterials in situ.

Further work is required to extend our knowledge on nanoparticle-mediated destabilization effects. In this respect, in situ analytical techniques such as SRCD combined with MD simulations represent a powerful analytical approach to investigate destabilization effects of nanoparticles on proteins in biological environments. Advanced methodologies by NMR ${ }^{31,32}$ and SANS ${ }^{0,75}$ have recently been developed to probe the formation of the protein corona in situ. They have given us access to a new observation window of NPs in biological environments. Similar techniques could be further extended to investigate the destabilization of proteins by NPs in situ.

\section{MATERIALS AND METHODS}

Purification of porcine oxyhemoglobin. Hemoglobin in its oxygenated form (oxyHb) was purified from fresh porcine blood (Sus scrofa domesticus) as described previously. 35 Briefly, oxyHb was extracted by erythrocyte membrane precipitation in $280 \mathrm{mM}$ phosphate buffer at $\mathrm{pH} 7$, dialyzed against pure water at $4^{\circ} \mathrm{C}$ using a membrane cut-off of $14 \mathrm{kDa}$ (Spectra/Pore), stripped on a mixed-bed ion-exchange resin (AG 501-X8, Bio-Rad), and centrifuged at 20 ,ooo g at $4^{\circ} \mathrm{C}$ for 10 min. The concentration of oxyHb expressed as heme molar concentration $(M=16,125 \mathrm{Da})$ was measured on a Shimadzu UV-2450 spectrophotometer using $\varepsilon_{576 \mathrm{~nm}}=15,150 \mathrm{M}^{-1} . \mathrm{cm}^{-1}$. Protein concentration and potential iron oxidation were checked before each experiments by recording the UV-vis spectrum in the $350 \mathrm{~nm}-700 \mathrm{~nm}$ range.

Silica nanoparticles. SNPs (Ludox TM-50, Sigma) were dialyzed against pure water at $4^{\circ} \mathrm{C}$ using a membrane cut-off of $3.5 \mathrm{kDa}$ (Spectra/Pore). Then the solution was diluted in pure water, sonicated and filtered through $0.45 \mu \mathrm{m}$ filters (Minisart). The SNP concentration was measured by drying $1 \mathrm{~mL}$ of the solution at $90^{\circ} \mathrm{C}$ overnight in open Eppendorf tubes and by weighing the final dry mass of 3 samples.

Synchrotron-radiation circular dichroism. Three buffers were used for the SRCD experiments: $100 \mathrm{mM}$ phosphate buffer pH 7 (Sigma 71649, Fisher Scientific S3720), 5 mM ammonium acetate $\left(\mathrm{NH}_{4} \mathrm{Ac}\right)$ buffer $\mathrm{pH} 9$ (Sigma A7330) and 3 $\mathrm{mM}$ N-Cyclohexyl-2-aminoethanesulfonic acid (CHES) buffer
pH 9 (Sigma C8210). The SNPs tend to buffer the solution towards basic $\mathrm{pH}$, especially at high concentration. A minimum concentration of $50 \mathrm{mM}$ phosphate buffer was required to maintain the solution at $\mathrm{pH} 7$ under our experimental conditions. Because of the buffering effect of SNPs, a smaller concentration of $\mathrm{CHES}$ or $\mathrm{NH}_{4} \mathrm{Ac}$ buffer was required at $\mathrm{pH}$ 9. All buffers are stable in the given temperature range. The SRCD experiments were conducted on the DISCO beamline at SOLEIL Synchrotron ${ }^{76}$ (Saint-Aubin, France). $1 \mathrm{mM}$ oxyHb was mixed with $100 \mathrm{mg} / \mathrm{mL}$ SNPs in $0.5 \mathrm{~mL}$ Eppendorf tubes and gently mixed on a wheel for 1 hour at $22^{\circ} \mathrm{C}$. The final $\mathrm{pH}$ of the solution was checked using a $\mathrm{pH}$ microelectrode (Biotrode, Metrohm). All the samples were vortexed at low speed for a few seconds before analysis. $4 \mu \mathrm{L}$ of the solution were deposited in a $\mathrm{CaF}_{2}$ round cell with a $12 \mu \mathrm{m}$ pathlength77 (Hellma). The pathlength was measured by light interference of an empty cell on a spectrophotometer in the visible domain. The spectra were recorded from $170 \mathrm{~nm}$ to $260 \mathrm{~nm}$. Temperature experiments were conducted from $22^{\circ} \mathrm{C}$ to $97^{\circ} \mathrm{C}$ with a $3^{\circ} \mathrm{C}$ step and an equilibration time of $5 \mathrm{~min}$. 3 scans were recorded at each temperature step. The experimental spectra were averaged, baseline subtracted and smoothed using CDtoolX software $^{78}$. The intensity of the SRCD signal was calibrated at $192 \mathrm{~nm}$ and at $290 \mathrm{~nm}$ with a standard solution of camphorsulfonic acid (CSA) analyzed in a $100 \mu \mathrm{m}$ pathlength cell at $22^{\circ} \mathrm{C}$ at a concentration of 6.19 g.L-1. The experimental spectra were converted from $\theta$ (millidegrees) to $\Delta \varepsilon$ (L.mol-1.cm-1) using a Mean Residue Weight (MRW) of 113.15 for porcine ox$\mathrm{yHb}$. The melting curves represented as $\Delta \varepsilon(194 \mathrm{~nm})$ and $\Delta \varepsilon(222 \mathrm{~nm})$ as a function of temperature were fitted by one or two successive sigmoids using Igor software. The same results were obtained by applying a two-sigmoidal curve equation to the melting curve following work by Rodnin et al.79

$$
\Delta \varepsilon=\frac{P_{1}}{1+e^{-\frac{\Delta H_{1}}{R T}\left(1-\frac{T}{T_{m 1}}\right)}}+\frac{P_{2}}{1+e^{-\frac{\Delta H_{2}}{R T}\left(1-\frac{T}{T_{m 2}}\right)}}
$$

where $\mathrm{P}_{1}, \mathrm{P}_{2}$ are the percentages associated with each transition.

Cryogenic transmission electron microscopy. $200 \mu \mathrm{M}$ oxyHb was mixed with $9 \mathrm{~g} / \mathrm{L}$ SNPs in $100 \mathrm{mM}$ phosphate buffer $\mathrm{pH} 7$ or in $5 \mathrm{mM} \mathrm{NH}_{4} \mathrm{Ac}$ buffer $\mathrm{pH} 9$ for th at room temperature. In these conditions, $56 \pm 4 \%$ oxyHb is adsorbed on SNPs at $\mathrm{pH}$, whereas no adsorbed protein was detected at $\mathrm{pH} 9$ $(<3 \%)$. A $4 \mu \mathrm{L}$ drop was deposited on a glow-discharged holey carbon grid (Quantifoil R2/2). The grid was blotted with a filter paper for $2 \mathrm{~s}$ and plunged into liquid ethane cooled down by liquid nitrogen using a Vitrobot Mark IV (Thermo Fisher Scientific). The nanoparticles were observed in areas without carbon film to reduce any potential effect of the grids on the samples. Frozen samples were transferred to a Gatan 626 cryoholder and observed on a JEOL 2010F cryo transmission electron microscope at $200 \mathrm{kV}$. A minimum of 2 grids per sample were observed and analyzed. Samples were imaged at x6oooo magnification using minimal dose system. Images were collected on a Gatan Ultrascan $4 \mathrm{~K}$ CCD camera with a $2.2 \mu \mathrm{m}$ nominal defocus. Automated image analysis was developed using ImageJ software for treatment and analysis. CryoTEM images were treated to reduce noise using the Non-local Means Denoising plugin and the Minimum Filter. Single nanoparticles and proteins in the corona were detected with the Particle Analysis plugin and the Watershed function. The same parameters were automatically applied to all the images 
(Table S1). A minimum of 100 nanoparticles were analyzed in each condition. A total number of 310 and 244 SNPs were analyzed with and without oxyHb respectively. The average SNP and protein diameters were calculated for a sphere from the area measured by automatic image analysis and expressed as mean \pm std. dev.

Secondary structure determination. The secondary structure of oxyHb was determined by deconvolution of the SRCD spectra with and without SNPs as a function of temperature with BeStSel algorithm. ${ }^{22,43}$ The structural analysis was validated by comparing the results with the crystal structure of porcine oxyHb. The secondary structure of oxyHb was calculated with DSSP tool from the crystal structure of porcine oxyHb 1QPW.pdb.44,45

Molecular dynamics simulations. Initial coordinates of ox$\mathrm{yHb}$ were obtained from the crystal structure available on the Protein Data Bank (1QPW.pdb). Crystallographic solvent atoms were removed from the structure. All atom simulations were performed with the AMBER 16 package. ${ }^{80}$ The ffogSBildn force field was employed for the protein and those of the heme were obtained from Giammona et al. ${ }^{81}$ The starting structures were immersed in a cubic box with boundaries extending from the protein periphery for at least $10 \AA$ in all directions. The box was filled with $\mathrm{TIP}_{3} \mathrm{P}$ water molecules, and an appropriate number of counter ions was added to neutralize the total charge of the system. The systems were minimized using steepest descent algorithm and used to initiate molecular dynamics. For each system, 4 molecular dynamic simulations were carried out at different temperatures: $295 \mathrm{~K}$, $322 \mathrm{~K}, 353 \mathrm{~K}$, and $400 \mathrm{~K}$. The SHAKE algorithm was used to constrain the motion of hydrogen-containing bonds within a $2 \mathrm{fs}$ time step to integrate the equations of motions. The cutoff distance for van der Waals interactions was set to $10 \AA$ and the Ewald particle mesh was used for long-range electrostatic interactions. Production runs of 150 ns were performed on the equilibrated structure with the NPT ensemble using a $2 \mathrm{fs}$ time step. The trajectories were clusterized with TTclust program ${ }^{82}$ and analysed with CPPTRAJ module, VMD $1.9 \cdot 3^{83}$ and Chimera 1.10.2 ${ }^{84}$ programs. The solvent-accessible surface area was calculated using the "surf" command in the CPPTRAJ module.

Density Functional Theory calculation. The interaction of the peptides with the silica surface was analyzed at the quantum chemistry level using Dispersion-Corrected Self Consistent Charge Density Functional Tight Binding (DCSCC-DFTB) with DFTB+ software ${ }^{5}$ using Lennard Jones forces from the universal force field. Parameters from the "matsci-o-3" set were used for the dispersion correction from the universal force field. ${ }^{85}$ The terminal $-\mathrm{CO}$ and $-\mathrm{NH}$ groups of the sequence were replaced by $\mathrm{H}$ atoms. The positions of the $\mathrm{N}$ and $\mathrm{C}$ atoms of the peptide bond were frozen for the initial minimization of the average peptide structure extracted from the MD simulation of the oxyHb structure. The silica surface was obtained with CHARMM GUI. ${ }^{86}$ During the interaction of the peptide with the silica surface, the $\mathrm{N}$ and $\mathrm{C}$ atoms of the two first residues only, were frozen. The peptides were positioned $2 \AA$ away from the silica surface at the beginning of the calculation, with the most mobile region corresponding to residues $50-56$ oriented towards the surface. The energy of the system
(445 atoms) was minimized by DC-SCC-DFTB using a conjugated gradient approach. The same approach was used for the calculation of the interaction with the silica slab and the silica cluster. The uncertainty on the calculated interaction energy is $0.2 \mathrm{eV}$.

Dynamic light scattering. The size of SNPs was measured in each buffer at $22^{\circ} \mathrm{C}$ by Dynamic Light Scattering (DLS). The measurement was performed on a Zetasizer Nano-ZS (Malvern Instruments) with a particle concentration of 0.01 $\mathrm{mg} / \mathrm{mL}$. Each measurement was repeated at least 3 times. The correlation coefficient measured by DLS was used to monitor the dissolution of the SNPs at $\mathrm{pH} 9$ over time. The SNP suspensions were analyzed after 3 days of incubation at $22^{\circ} \mathrm{C}$ in $\mathrm{NH}_{4}$ Ac buffer and in CHES buffer at $\mathrm{pH}$ 9. The zeta potential

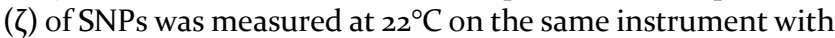
a particle concentration of $1 \mathrm{mg} / \mathrm{mL}$. Each measurement was repeated at least 3 times. The $\zeta$-potential was calculated by fitting the electrophoretic mobility with the Smoluchowski model.

Adsorption isotherms. The same conditions of incubation of oxyHb with SNPs were used for the SRCD experiments and for the measurement of the adsorption isotherms. After incubation, the samples were centrifuged at 30,000 $\mathrm{g}$ for 20 minutes. The concentration of oxyHb in the supernatant was measured by spectrophotometry on a Shimadzu UV-2450 spectrophotometer. The adsorption of oxyHb on SNPs was measured at $22^{\circ} \mathrm{C}, 30^{\circ} \mathrm{C}, 40^{\circ} \mathrm{C}$, and $50^{\circ} \mathrm{C}$ in each buffer condition. The experiments were performed in triplicate. The amount of adsorbed oxyHb is expressed as average \pm standard deviation.

\section{ASSOCIATED CONTENT}

Supporting Information. Characterization of SNPs; analysis of cryoTEM images; secondary structure determination; thermal unfolding of oxyHb; protonation state of histidine in oxyHb structure; MD simulation of oxyHb structure; calculation of the surface accessibility of oxyHb; DC-SCC-DFTB calculation of peptide-silica interactions; thermodynamic analysis of oxyHb unfolding. This material is available free of charge via the Internet at http://pubs.acs.org.

\section{AUTHOR INFORMATION}

\section{Corresponding author}

*stephanie.devineau@u-paris.fr

\section{Author Contributions}

SD, SP and JPR designed the study. SD, DSG and FW performed the SRCD experiments. LM and JD carried out cryoTEM imaging. GCC contributed to sample preparation and measured the adsorption isotherms. YB performed the MD simulations. JPR performed DFTB calculations. SD developed thermodynamic data analysis with input from JPR. SD wrote the manuscript. All authors discussed the results and contributed to the final manuscript.

\section{ACKNOWLEDGMENT}

We thank the CEA-CCRT infrastructure for access to the COBALT supercomputer. SRCD experiments at DISCO beamline were supported by Synchrotron SOLEIL (Proposal $\mathrm{n}^{\circ}$ 20180059). CryoTEM experiments were supported by the 
METSA network (Proposal FR3507) and by the French Investissements d'Avenir LabEx PALM (ANR-10LABX-oo39PALM).

\section{REFERENCES}

(1) Deng, Z. J.; Liang, M.; Monteiro, M.; Toth, I.; Minchin, R. F. Nanoparticle-Induced Unfolding of Fibrinogen Promotes Mac-1 Receptor Activation and Inflammation. Nat. Nanotechnol. 2011, 6 (1), 39-44.

(2) Walkey, C. D.; Chan, W. C. W. Understanding and Controlling the Interaction of Nanomaterials with Proteins in a Physiological Environment. Chem. Soc. Rev. 2012, 41 (7), 27802799.

(3) Monopoli, M. P.; Åberg, C.; Salvati, A.; Dawson, K. A. Biomolecular Coronas Provide the Biological Identity of Nanosized Materials. Nat. Nanotechnol. 2012, 7 (12), 779-786.

(4) Lara, S.; Alnasser, F.; Polo, E.; Garry, D.; Cristina, M.; Giudice, L.; Hristov, D. R.; Rocks, L.; Salvati, A.; Yan, Y.; Dawson, K. A. Identification of Receptor Binding to the Biomolecular Corona of Nanoparticles. ACS Nano 2017, 11, 1884-1893.

(5) Konduru, N. V.; Molina, R. M.; Swami, A.; Damiani, F.; Pyrgiotakis, G.; Lin, P.; Andreozzi, P.; Donaghey, T. C.; Demokritou, P.; Krol, S.; Kreyling, W.; Brain, J. D. Protein Corona: Implications for Nanoparticle Interactions with Pulmonary Cells. Part. Fibre Toxicol. 2017, 14 (1), 1-12.

Ho, Y. T.; Kamm, R. D.; Kah, J. C. Y. Influence of Protein Corona and Caveolae-Mediated Endocytosis on Nanoparticle Uptake and Transcytosis. Nanoscale 2018, 10 (26), 1238612397.

(7) Lesniak, A.; Fenaroli, F.; Monopoli, M. P.; Åberg, C.; Dawson, K. A.; Salvati, A. Effects of the Presence or Absence of a Protein Corona on Silica Nanoparticle Uptake and Impact on Cells. ACS Nano 2012, 6 (7), 5845-5857.

Tenzer, S.; Docter, D.; Kuharev, J.; Musyanovych, A.; Fetz, V.; Hecht, R.; Schlenk, F.; Fischer, D.; Kiouptsi, K.; Reinhardt, C.; Landfester, K.; Schild, H.; Maskos, M.; Knauer, S. K.; Stauber, R. H. Rapid Formation of Plasma Protein Corona Critically Affects Nanoparticle Pathophysiology. Nat. Nanotechnol. 2013, 8 (10), 772-781.

(9) Mahmoudi, M.; Lynch, I.; Ejtehadi, M. R.; Monopoli, M. P.; Bombelli, F. B.; Laurent, S. Protein-Nanoparticle Interactions: Opportunities and Challenges. Chem. Rev. 2011, 111 (9), 5610-5637.

(10) Sanfins, E.; Dairou, J.; Hussain, S.; Busi, F.;
Chaffotte, A. F.; Rodrigues-Lima, F.; Dupret, J. M. Carbon Black Nanoparticles Impair Acetylation of Aromatic Amine Carcinogens through Inactivation of Arylamine N Acetyltransferase Enzymes. ACS Nano 2011, 5 (6), 4504-4511.

(11) Vertegel, A. A.; Siegel, R. W.; Dordick, J. S. Silica Nanoparticle Size Influences the Structure and Enzymatic Activity of Adsorbed Lysozyme. Langmuir 2004, 20 (16), 6800-6807.

(12) Devineau, S.; Zanotti, J. M.; Loupiac, C.; Zargarian, L.; Neiers, F.; Pin, S.; Renault, J. P. Myoglobin on Silica: A Case Study of the Impact of Adsorption on Protein Structure and Dynamics. Langmuir 2013, 29 (44), 13465-13472.

(13) Mathé, C.; Devineau, S.; Aude, J. C.; Lagniel, G.; Chédin, S.; Legros, V.; Mathon, M. H.; Renault, J. P.; Pin, S.; Boulard, Y.; Labarre, J. Structural Determinants for Protein Adsorption/NonAdsorption to Silica Surface. PLoS One 2013, 8 (11), 1-13.

(14) Marichal, L.; Renault, J. P.; Chédin, S.; Lagniel, G.; Klein, G.; Aude, J. C.; Tellier-Lebegue, C.; Armengaud, J.; Pin, S.; Labarre, J.; Boulard, Y. Importance of Post-Translational Modifications in the Interaction of Proteins with Mineral Surfaces: The Case of Arginine Methylation and Silica Surfaces. Langmuir 2018, 34 (18), 53125322.

(15) Cedervall, T.; Lynch, I.; Lindman, S.; Berggård, T.; Thulin, E.; Nilsson, H.; Dawson, K. A.; Linse, S. Understanding the Nanoparticle-Protein Corona Using Methods to Quntify Exchange Rates and Affinities of Proteins for Nanoparticles. Proc. Natl. Acad. Sci. U. S. A. 2007, 104 (7), 2050-2055.

(16) Lundqvist, M.; Stigler, J.; Elia, G.; Lynch, I.; Cedervall, T.; Dawson, K. A. Nanoparticle Size and Surface Properties Determine the Protein Corona with Possible Implications for Biological Impacts. Proc. Natl. Acad. Sci. U. S. A. 2008, 105 (38), 14265-14270.

(17) Angioletti-Uberti, S.; Ballauff, M.; Dzubiella, J. Competitive Adsorption of Multiple Proteins to Nanoparticles: The Vroman Effect Revisited. Mol. Phys. 2018, 116 (21-22), 3154-3163.

(18) Pisani, C.; Gaillard, J. C.; Odorico, M.; Nyalosaso, J. L.; Charnay, C.; Guari, Y.; Chopineau, J.; Devoisselle, J. M.; Armengaud, J.; Prat, O. The Timeline of Corona Formation around Silica Nanocarriers Highlights the Role of the Protein Interactome. Nanoscale 2017, 9, 1840-1851.

(19) Cox, A.; Andreozzi, P.; Dal Magro, R.; Fiordaliso, F.; Corbelli, A.; Talamini, L.; Chinello, C.; 
Raimondo, F.; Magni, F.; Tringali, M.; Krol, S.; Jacob Silva, P.; Stellacci, F.; Masserini, M.; Re, F. Evolution of Nanoparticle Protein Corona across the Blood-Brain Barrier. ACS Nano 2018, 12 (7), 7292-7300.

(20) Bertoli, F.; Garry, D.; Monopoli, M. P.; Salvati, A.; Dawson, K. A. The Intracellular Destiny of the Protein Corona: A Study on Its Cellular Internalization and Evolution. ACS Nano 2016, 10 (11), 10471-10479.

(21) Hadjidemetriou, M.; Al-Ahmady, Z.; Kostarelos, K. Time-Evolution of In Vivo Protein Corona onto Blood-Circulating PEGylated Liposomal Doxorubicin (DOXIL) Nanoparticles. Nanoscale 2016, 8 (13), 6948-6957.

(22) Palchetti, S.; Colapicchioni, V.; Digiacomo, L.; Caracciolo, G.; Pozzi, D.; Capriotti, A. L.; La Barbera, G.; Laganà, A. The Protein Corona of Circulating PEGylated Liposomes. Biochim. Biophys. Acta - Biomembr. 2016, 1858 (2), 189196.

(23) Hadjidemetriou, M.; Kostarelos, K. Nanomedicine: Evolution of the Nanoparticle Corona. Nat. Nanotechnol. 2017, 12 (4), 288-290.

(24) Baimanov, D.; Cai, R.; Chen, C. Understanding the Chemical Nature of Nanoparticle-Protein Interactions. Bioconjug. Chem. 2019, 30, 19231937.

(25) Winzen, S.; Schoettler, S.; Baier, G.; Rosenauer, C.; Mailaender, V.; Landfester, K.; Mohr, K. Complementary Analysis of the Hard and Soft Protein Corona: Sample Preparation Critically Effects Corona Composition. Nanoscale 2015, 7 (7), 2992-3001.

(26) Pisani, C.; Gaillard, J. C.; Dorandeu, C.; Charnay, C.; Guari, Y.; Chopineau, J.; Devoisselle, J. M.; Armengaud, J.; Prat, O. Experimental Separation Steps Influence the Protein Content of Corona around Mesoporous Silica Nanoparticles. Nanoscale 2017, 9 (18), 5769-5772.

(27) Weber, C.; Morsbach, S.; Landfester, K. Possibilities and Limitations of Different Separation Techniques for the Analysis of the Protein Corona. Angew. Chemie Int. Ed. 2019, 110.

(28) Lo Giudice, M. C.; Herda, L. M.; Polo, E.; Dawson, K. A. In Situ Characterization of Nanoparticle Biomolecular Interactions in Complex Biological Media by Flow Cytometry. Nat. Commun. 2016, 7, 1-10.

(29) Shang, L.; Nienhaus, G. U. In Situ Characterization of Protein Adsorption onto Nanoparticles by Fluorescence Correlation Spectroscopy. Acc. Chem. Res. 2017, 50 (2), 387-
395.

(30) Marichal, L.; Giraudon--Colas, G.; Cousin, F.; Thill, A.; Labarre, J.; Boulard, Y.; Aude, J.-C.; Pin, S.; Renault, J. P. Protein-Nanoparticle Interactions: What Are the Protein-Corona Thickness and Organization? Langmuir 2019.

(31) Carril, M.; Padro, D.; Del Pino, P.; CarrilloCarrion, C.; Gallego, M.; Parak, W. J. In Situ Detection of the Protein Corona in Complex Environments. Nat. Commun. 2017, 8 (1).

(32) Assfalg, M.; Ragona, L.; Pagano, K.; D’Onofrio, M.; Zanzoni, S.; Tomaselli, S.; Molinari, H. The Study of Transient Protein-Nanoparticle Interactions by Solution NMR Spectroscopy. Biochim. Biophys. Acta - Proteins Proteomics 2016, 1864 (1), 102-114.

(33) Weiss, A. C. G.; Krüger, K.; Besford, Q. A.; Schlenk, M.; Kempe, K.; Förster, S.; Caruso, F. In Situ Characterization of Protein Corona Formation on Silica Microparticles Using Confocal Laser Scanning Microscopy Combined with Microfluidics. ACS Appl. Mater. Interfaces 2019, 11 (2), 2459-2469.

(34) Zoungrana, T.; Findenegg, G. H.; Norde, W. Structure, Stability, and Activity of Adsorbed Enzymes. J. Colloid Interface Sci. 1997, 190 (2), 437-448.

（35） Devineau, S.; Zargarian, L.; Renault, J. P.; Pin, S. Structure and Function of Adsorbed Hemoglobin on Silica Nanoparticles: Relationship between the Adsorption Process and the Oxygen Binding Properties. Langmuir 2017, 33 (13), 3241-3252.

(36) Orts-Gil, G.; Natte, K.; Drescher, D.; Bresch, H.; Mantion, A.; Kneipp, J.; Österle, W. Characterisation of Silica Nanoparticles Prior to In Vitro Studies: From Primary Particles to Agglomerates. J. Nanoparticle Res. 2011, 13 (4), 1593-1604.

（37） Devineau, S.; Kiger, L.; Galacteros, F.; BaudinCreuza, V.; Marden, M.; Renault, J. P.; Pin, S. Manipulating Hemoglobin Oxygenation Using Silica Nanoparticles: A Novel Prospect for Artificial Oxygen Carriers. Blood Adv. 2018, 2 (2), 90-94.

(38) Langmuir, I. The Adsorption of Gases on Plane Surfaces of Glass, Mica and Platinum. J. Am. Chem. Soc. 1918, 40, 1361-1403.

(39) Wallace, B. A. Conformational Changes by Synchrotron Radiation Circular Dichroism Spectroscopy. Nat. Struct. Biol. 200o, 7 (9), 708709 .

(40) Ma, W.; Saccardo, A.; Roccatano, D.; AboagyeMensah, D.; Alkaseem, M.; Jewkes, M.; Di Nezza, 
F.; Baron, M.; Soloviev, M.; Ferrari, E. Modular Assembly of Proteins on Nanoparticles. Nat. Commun. 2018, 9 (1), 1-9.

(41) Jiang, J.; Abramavicius, D.; Bulheller, B. M.; Hirst, J. D.; Mukamel, S. Ultraviolet Spectroscopy of Protein Backbone Transitions in Aqueous Solution: Combined QM and MM Simulations. J. Phys. Chem. B 2010, 114 (24), 8270-8277.

(42) Micsonai, A.; Wien, F.; Kernya, L.; Lee, Y.-H.; Goto, Y.; Réfrégiers, M.; Kardos, J. Accurate Secondary Structure Prediction and Fold Recognition for Circular Dichroism Spectroscopy. Proc. Natl. Acad. Sci. U. S. A. 2015, 112 (24), 1-9.

(43) Micsonai, A.; Wien, F.; Bulyáki, É.; Kun, J.; Moussong, É.; Lee, Y. H.; Goto, Y.; Réfrégiers, M.; Kardos, J. BeStSel: A Web Server for Accurate Protein Secondary Structure Prediction and Fold Recognition from the Circular Dichroism Spectra. Nucleic Acids Res. 2018, 46 (1), 315-322.

(44) Kabsch, W.; Sander, C. Dictionary of Protein Secondary Structure: Pattern Recognition of Hydrogen-Bonded and Geometrical Features. Biopolymers 1983, 22, 2577-2637.

(45) Touw, W. G.; Baakman, C.; Black, J.; Te Beek, T. A. H.; Krieger, E.; Joosten, R. P.; Vriend, G. A Series of PDB-Related Databanks for Everyday Needs. Nucleic Acids Res. 2015, 43 (1), 364-368.

(46) Chen, W. T.; Chen, Y. C.; Liou, H. H.; Chao, C. Y. Structural Basis for Cooperative Oxygen Binding and Bracelet-Assisted Assembly of Lumbricus Terrestris Hemoglobin. Sci. Rep. 2015, 5, 1-8.

(47) Jiang, J.; Abramavicius, D.; Bulheller, B. M.; Hirst, J. D.; Mukamel, S. Ultraviolet Spectroscopy of Protein Backbone Transitions in Aqueous Solution: Combined QM and MM Simulations. J. Phys. Chem. B 2010, 114 (24), 8270-8277.

(48) Yan, Y. Bin; Wang, Q.; He, H. W.; Zhou, H. M. Protein Thermal Aggregation Involves Distinct Regions: Sequential Events in the Heat-Induced Unfolding and Aggregation of Hemoglobin. Biophys. J. 2004, 86 (3), 1682-169o.

(49) Steadman, B. L.; Thompson, K. C.; Middaugh, C. R.; Matsuno, K.; Vrona, S.; Lawson, E. Q.; Lewis, R. V. The Effects of Surface Adsorption on the Thermal Stability of Proteins. Biotechnol. Bioeng. 1992, 40 (1), 8-15.

(50) Larsericsdotter, H.; Oscarsson, S.; Buijs, J. Thermodynamic Analysis of Proteins Adsorbed on Silica Particles: Electrostatic Effects. J. Colloid Interface Sci. 2001, 237 (1), 98-103.

(51) Antonini, E.; Brunori, M. Hemogobin and
Myoglobin in Their Interactions with Ligands, Frontiers.; North Holland Publishing Company, 1971.

(52) Meissner, J.; Prause, A.; Bharti, B.; Findenegg, G. H. Characterization of Protein Adsorption onto Silica Nanoparticles: Influence of $\mathrm{PH}$ and Ionic Strength. Colloid Polym. Sci. 2015, 293 (11), 33813391.

(53) Lippert, T.; Rarey, M. Fast Automated Placement of Polar Hydrogen Atoms in ProteinLigand Complexes. J. Cheminform. 2oo9, 1 (1), 112.

（54） Bietz, S.; Urbaczek, S.; Schulz, B.; Rarey, M. Protoss: A Holistic Approach to Predict Tautomers and Protonation States in ProteinLigand Complexes. J. Cheminform. 2014, 6 (1), 112.

（55） Søndergaard, C. R.; Olsson, M. H. M.; Rostkowski, M.; Jensen, J. H. Improved Treatment of Ligands and Coupling Effects in Empirical Calculation and Rationalization of PKa Values. J. Chem. Theory Comput. 2011, 7 (7), 2284-2295.

(56) Olsson, M. H. M.; Søndergaard, C. R.; Rostkowski, M.; Jensen, J. H. PROPKA3: Consistent Treatment of Internal and Surface Residues in Empirical PKa Predictions. J. Chem. Theory Comput. 2011, 7 (2), 525-537.

(57) Bekker, G.-J.; Ma, B.; Kamiya, N. Thermal Stability of Single-domain Antibodies Estimated by Molecular Dynamics Simulations. Protein Sci. 2019, 28, 429-438.

(58) Aradi, B.; Hourahine, B.; Frauenheim, T. DFTB+, a Sparse Matrix-Based Implementation of the DFTB Method. J. Phys. Chem. A 2007, 111 (26), 5678-5684.

（59） Ortega, G.; Kurnik, M.; Dauphin-Ducharme, P.; Li, H.; Arroyo-Currás, N.; Caceres, A.; Plaxco, K. W. Surface Attachment Enhances the Thermodynamic Stability of Protein L. Angew. Chemie - Int. Ed. 2019, 58 (6), 1714-1718.

(6o) Edwards, D. T.; Yu, H.; Siewny, M. G. W.; Perkins, T. T.; Sanders, A. W. Hidden Dynamics in the Unfolding of Individual Bacteriorhodopsin Proteins. Science (80-. ). 2017, 355 (6328), 945-950.

(61) Klein, G.; Devineau, S.; Aude, J. C.; Boulard, Y.; Pasquier, H.; Labarre, J.; Pin, S.; Renault, J. P. Interferences of Silica Nanoparticles in Green Fluorescent Protein Folding Processes. Langmuir 2016, 32 (1), 195-202.

(62) Gros, P.; Milder, F. J.; Janssen, B. J. C. Complement Driven by Conformational Changes. Nat. Rev. Immunol. 20o8, 8 (1), 48-58. 
(63) Hamad, I.; Christy Hunter, A.; Rutt, K. J.; Liu, Z.; Dai, H.; Moein Moghimi, S. Complement Activation by PEGylated Single-Walled Carbon Nanotubes Is Independent of $\mathrm{C}_{1 \mathrm{q}}$ and Alternative Pathway Turnover. Mol. Immunol. 2008, 45 (14), 3797-3803.

(64) Mahmoudi, M.; Abdelmonem, A. M.; Behzadi, S.; Clement, J. H.; Dutz, S.; Ejtehadi, M. R.; Hartmann, R.; Kantner, K.; Linne, U.; Maffre, P.; Metzler, S.; Moghadam, M. K.; Pfeiffer, C.; Rezaei, M.; Ruiz-Lozano, P.; Serpooshan, V.; Shokrgozar, M. A.; Nienhaus, G. U.; Parak, W. J. Temperature: The "Ignored" Factor at the NanoBio Interface. ACS Nano 2013, 7 (8), 65556562.

(65) Gorshkov, V.; Bubis, J. A.; Solovyeva, E. M.; Gorshkov, M. V.; Kjeldsen, F. Protein Corona Formed on Silver Nanoparticles in Blood Plasma Is Highly Selective and Resistant to Physicochemical Changes of the Solution. Environ. Sci. Nano 2019.

(66) Simon, J.; Müller, J.; Ghazaryan, A.; Morsbach, S.; Mailänder, V.; Landfester, K. Protein Denaturation Caused by Heat Inactivation Detrimentally Affects Biomolecular Corona Formation and Cellular Uptake. Nanoscale 2018, 10 (45), 21096-21105.

(67) Greenfield, N. J. Using Circular Dichroism Collected as a Funcion of Temperature to Determine the Thermodynamics of Protein Unfolding and Binding Interactions. Nat. Protoc. 2006, 1 (6), 1-19.

(68) Benjwal, S.; Verma, S.; Rohm, K.; Gursky, O. Monitoring Protein Aggregation during Thermal Unfolding in Circular Dichroism Experiments. Protein Sci. 2oo6, 15 (3), 635-639.

(69) Kazlauskas, R. Engineering More Stable Proteins. Chem. Soc. Rev. 2018, 47 (24), 90269045.

(70) Senske, M.; Törk, L.; Born, B.; Havenith, M.; Herrmann, C.; Ebbinghaus, S. Protein Stabilization by Macromolecular Crowding through Enthalpy Rather than Entropy. J. Am. Chem. Soc. 2014, 136, 9036-9041.

(71) Christiansen, A.; Wittung-Stafshede, P. Quantification of Excluded Volume Effects on the Folding Landscape of Pseudomonas Aeruginosa Apoazurin In Vitro. Biophys. J. 2013, 105 (7), 1689-1699.

(72) Kumar, R.; Sharma, D.; Kumar, V.; Kumar, R. Factors Defining the Effects of Macromolecular Crowding on Dynamics and Thermodynamic Stability of Heme Proteins In Vitro. Arch. Biochem. Biophys. 2018, 654 (July), 146-162.
(73) Kari, O. K.; Ndika, J.; Parkkila, P.; Louna, A.; Lajunen, T.; Puustinen, A.; Viitala, T.; Alenius, H.; Urtti, A. In Situ Analysis of Liposome Hard and Soft Protein Corona Structure and Composition in a Single Label-Free Workflow. Nanoscale 2020, 12 (3), 1728-1741.

(74) Wang, J.; Jensen, U. B.; Jensen, G. V.; Shipovskov, S.; Balakrishnan, V. S.; Otzen, D.; Pedersen, J. S.; Besenbacher, F.; Sutherland, D. S. Soft Interactions at Nanoparticles Alter Protein Function and Conformation in a Size Dependent Manner. Nano Lett. 2011, 11 (11), 4985-4991.

（75） Meissner, J.; Wu, Y.; Jestin, J.; Shelton, W. A.; Findenegg, G. H.; Bharti, B. PH-Induced Reorientation of Cytochrome c on Silica Nanoparticles. Soft Matter 2019, 15 (3), 350-354.

(76) Réfrégiers, M.; Wien, F.; Ta, H. P.; Premvardhan, L.; Bac, S.; Jamme, F.; Rouam, V.; Lagarde, B.; Polack, F.; Giorgetta, J. L.; Ricaud, J. P.; Bordessoule, M.; Giuliani, A. DISCO Synchrotron-Radiation Circular-Dichroism Endstation at SOLEIL. J. Synchrotron Radiat. 2012, 19 (5), 831-835.

(77) Wien, F.; Wallace, B. A. Calcium Fluoride Micro Cells for Synchrotron Radiation Circular Dichroism Spectroscopy. Appl. Spectrosc. 2005, 59 (9), 1109-1113.

(78) Miles, A. J.; Wallace, B. A. CDtoolX, a Downloadable Software Package for Processing and Analyses of Circular Dichroism Spectroscopic Data. Protein Sci. 2018, 27 (9), 1717-1722.

（79） Rodnin, M. V.; Posokhov, Y. O.; Contino-Pépin, C.; Brettmann, J.; Kyrychenko, A.; Palchevskyy, S. S.; Pucci, B.; Ladokhin, A. S. Interactions of Fluorinated Surfactants with Diphtheria Toxin T-Domain: Testing New Media for Studies of Membrane Proteins. Biophys. J. 2008, 94 (11), 4348-4357.

(8o) Case, D. A.; Darden, T. A.; Cheatham, T. E.; Simmerling, C. L.; Wang, J.; Duke, R. E.; Luo, R.; Walker, R. C.; Zhang, W.; Merz, K. M.; Roberts, B.; Hayik, S.; Roitberg, A.; Seabra, G.; Swails, J.; Goetz, A. W.; Kolossvai, I.; Wong, K. F.; Paesani, F.; Vanicek, J.; Wolf, R. M.; Kollman, P. A. AMBER. University of California, San Fransisco 2012.

(81) Giammona, D.; Case, D.; Bayly, C. Force Field Modification for All-Atom Heme. 1995.

(82) Tubiana, T.; Carvaillo, J. C.; Boulard, Y.; Bressanelli, S. TTClust: A Versatile Molecular Simulation Trajectory Clustering Program with Graphical Summaries. J. Chem. Inf. Model. 2018, 
58 (11), 2178-2182.

(83) Humphrey, W.; Dalke, A.; Schulten, K. VMD: Visual Molecular Dynamics. J. Mol. Graph. 1996, 14 (October 1995), 33-38.

(84) Pettersen, E. F.; Goddard, T. D.; Huang, C. C.; Couch, G. S.; Greenblatt, D. M.; Meng, E. C.; Ferrin, T. E. UCSF Chimera - A Visualization System for Exploratory Research and Analysis. J. Comput. Chem. 2004, 25 (13), 1605-1612.

(85) J. Frenzel; Oliveira, A. F.; Jardillier, N.; T, H.; Seifert, G. Semi-Relativistic, Self-Consistent
Charge Slater-Koster Tables for DensityFunctional Based Tight-Binding (DFTB) for Materials Science Simulations.

(86) Jo, S.; Cheng, X.; Lee, J.; Kim, S.; Park, S. J.; Patel, D. S.; Beaven, A. H.; Lee, K. Il; Rui, H.; Park, S.; Lee, H. S.; Roux, B.; MacKerell, A. D.; Klauda, J. B.; Qi, Y.; Im, W. CHARMM-GUI o Years for Biomolecular Modeling and Simulation. J. Comput. Chem. 2017, 38 (15), 1114-1124. 
TOC graphic.

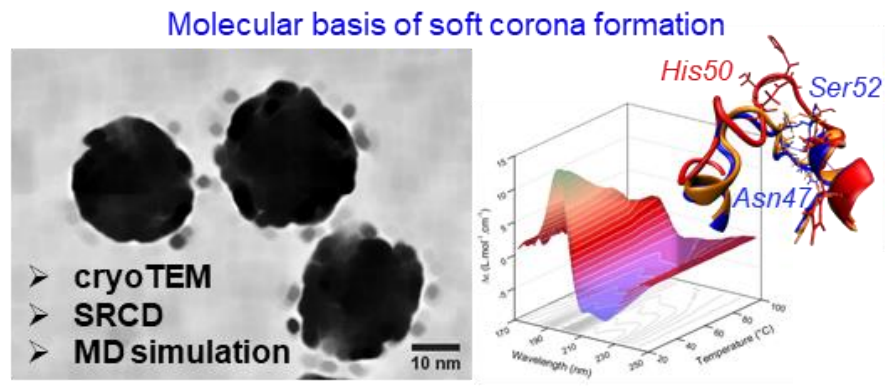

19 